\title{
An Exploration of the Significance of the Father's Body Movement Play with Infant Child of Becoming a Father: Focusing on Experience at the G Play Education Institute
}

\author{
Hye Ryun Kim ${ }^{1}$, Eunju Yun ${ }^{2}$ \\ Ph. D. Student, Department of Child Welfare and Studies, Sookmyung Women's University, Seoul, Korea ${ }^{1}$ \\ Professor, Department of Child Welfare and Studies, Sookmyung Women's University, Seoul, Korea ${ }^{2}$ \\ 영아기 자녀와의 신체동작 놀이가 아버지 되기 경험에 주는 의미 탐구: \\ $\mathrm{G}$ 영유아 놀이 교육 기관 경험을 중심으로 \\ 김혜련 ${ }^{1}$, 윤은주 $^{2}$ \\ 숙명여자대학교 아동복지학부 박사과정생 ${ }^{1}$, 숙명여자대학교 아동복지학부 교수 ${ }^{2}$
}

\begin{abstract}
Objectives: This study aimed to investigate how the aspect of body movement play appears between father and infant child and explore the significance of the results on being a father.

Methods: The G play education institute which specializes in having parents participate in infant play education, was selected as the study site, six fathers with their first infant child who signed up at the G play education institute were selected as study participants. In-depth interviews and participant observation were conducted for three months from September to November 2016.

Results: The body movements plays of the fathers with their infant child were categorized into 'bodylimited play', 'gender role-limited play', 'play transmitted over the generations', and 'burdensome play'. In analyzing the significance of body movement play with an infant child to the experience of a man transitioning into a father figure, the following were shown to be significant: 'relationship building through body interaction', 'a transition from my individual self into a father figure', 'being born again to a mature father', and 'adding family happiness through body movement play'.

Conclusion: The results showed that body movement play between the father and the child, which is being emphasized and re-highlighted as a representative parenting form of fathers helped in relationship building, enhancing parenting capability, fostering parents' capability of ensuring the child's growth and development as well as encouraging growth and adulthood development during the turning point that is fatherhood. It also implies that fathers contribute to family happiness through their self-reflection and growth.
\end{abstract}

Keywords: father with an infant child, body movement play, being a father

\section{Introduction}

영아는 움직임을 통해 대상을 탐색하고, 실험하고, 조작함으로

Corresponding Author: Eunju Yun, Professor, Department of Child Welfare \& Studies, Sookmyung Women's University, 100, Cheongpa-ro 47-gil, Yongsan-gu, Seoul, Korea

E-mail: eunjuyun@sookmyung.ac.kr
써 주변 세계를 인식하며 다양한 환경을 경험한다(J.-Y. Kwon, Chung, \& Yee, 2015). 또한 영아는 신체 움직임에서 이뤼지는 감각작용만으로 대상을 인식하는 것이 아니라 몸을 기초로

(C)The Korean Association of Child Studies

This is an Open Access article distributed under the terms of the Creative Commons Attribution Non-Commercial License (http:// creativecommons.org/licenses/by-nc/4.0) which permits unrestricted noncommercial use, distribution, and reproduction in any medium, provided the original work is properly cited. 
해서 동작을 하고, 이를 통해 직접적 지각을 하는 '몸적 이성 (Merleau-Ponty, 1976/2002)'이다(Lim, Kim, \& Park, 2008). 그렇 기에 영아에게 있어서 동작은 단순한 신체 움직임 이상의 의미 를 지니며, 이러한 동작과 가장 깊은 관련을 맺고 있는 것이 바 로 놀이다(Y. Park, 2013). 신체 움직임이 중심이 되는 영아의 놀 이는 신체화된 경험(embodied experience)으로서 부모와의 상호 작용을 경험하게 하고, 영아발달을 도모하는 중요한 활동이다 (S.-Y. Kim, 2010; Lim et al., 2008). 영아의 발달에 영향을 미치는 환경적 변인 중에서도 부모의 역할은 그 무엇보다 비중이 크 다(S.-Y. Kim, 2012). 보살핌이 절대적으로 필요한 영아에게 부 모는 양육자이자 애착형성의 주대상자로서 역할을 수행한다 (B. Lee, 2010). 이러한 이유로 부모와 영아 간 상호작용을 탐구 한 연구들 중에서 가장 많이 논의되는 주제 가운데 하나가 바 로 '놀이 파트너로서의 부모'이다(Choi, 2005). 그런데 최근 이 분야에서 아버지를 대상으로 한 연구가 눈에 띄게 늘고 있음을 발견하게 된다. 놀이 참여 및 상호작용에 있어서 어머니와 아 버지의 역할에서 서로 차이가 나타나기 때문이다. 관련 연구들 에 의하면 어머니의 경우 주로 인지적·언어적인 정적 측면에 영향을 미치는 반면, 아버지의 경우 신체적·활동적인 동적 측 면에 영향을 주는 것으로 밝혀졌다(J.-Y. Kwon et al., 2015). 따 라서 영아는 아버지와의 놀이 상호작용을 통해 어머니와는 질 적으로 다른 자극을 받게 되는데, 이것은 어머니와의 정적인 상호작용만으로는 부족한 발달 특성을 아버지를 통해 채우게 된다는 것을 의미한다. 이처럼 아버지와 어머니의 놀이가 영아 에게 미치는 서로 다른 긍정적 영향을 고려할 때, 영아의 균형 적 발달을 위해서는 어머니뿐만 아니라 아버지의 놀이 참여가 필수임을 알 수 있다(S.-Y. Kim, 2012). 최근 영아기 자녀양육에 있어 아버지의 역할 중 신체 놀이가 더욱 중요시 되고 있는 이 유도 바로 여기에 있다(Oh, Cho, \& Kang, 2000).

아버지의 놀이 참여에 대한 연구가 지속적으로 증가하는 현 상은 자녀 양육에서 아버지의 중요성을 점점 더 강조하는 요즈 음의 연구 경향과도 관련이 있다. 핵가족화와 여성 취업, 맞벌 이 부부 증가 등 현대사회의 변화는 자녀 양육에서 아버지의 적 극적 참여를 요청하고 있다(H.-K. Kwon, 2009). 그 결과 아버지 는 자녀 양육의 부차적 존재에서 벗어나 양육의 주체로서 새롭 게 조명 받고 있다(N. H. Kim, 2011; Y.-I. Kim \& Kim, 2015).

이렇듯 아버지 역할에 대한 새로운 인식은 놀이 활동에 더 뛰어난 강점을 발휘하는 아버지의 특성에 따라, 자연스럽게 놀이 활동에 초점을 맞추게 된다. 아버지 양육참여를 통한 영 아발달과의 관련성에 대해 밝힌 선행연구(Han, 2006; H.-K. Kwon, 2009; Ryu \& Lee, 2013)들도 아버지의 놀이 참여에 대
해 주목한 것들이다. 그런데, 놀이는 기본적으로 상호성을 전 제로 하는 것이어서 아버지의 자녀 놀이 참여는 단지 영아의 발달에만 영향을 미치는 것은 아니라는 사실에 주목할 필요가 있다. S. Park과 Lee (2013)의 연구에 의하면 타인과의 관계를 통해 이뤄지는 일반적 동작 놀이와 마찬가지로 아버지와 영아 간의 놀이 상호작용 역시 상보적 관계를 형성하도록 하여 아 버지 자신에게도 긍정적 영향을 미친다. 즉 아버지로서의 자 긍심을 높이며, 무엇보다 아버지 역할에 대한 만족감 향상에 직접적 영향을 주게 된다.

하지만 아버지 양육참여에 대한 인식의 변화, 아버지 놀이 에 대한 관심의 증가에도 불구하고, 실제에 있어서는 아버지 와 영유아기 자녀와의 신체적 상호작용이 적은 편으로 조사 된다(Jung, Kim, Kim, \& Yoo, 2010; Oh et al., 2000). 이로 인해 서 자녀와의 신체 활동 참여시간을 확대할 수 있도록 아버지 를 대상으로 하는 부모 교육 프로그램이 개발, 실행되어야 한 다는 요구들이 제시되기도 한다(Jung et al., 2010). 양육의 당 사자인 아버지들 또한 자녀양육에 참여하여 아버지의 역할을 더 잘 수행하기를 원하고, 구체적으로 자녀와 함께 지내는 시 간을 효과적으로 활용하기 위한 방법을 배우고 싶어 한다(Lee, Kim, \& Woo, 2006).

또한 대부분의 아버지-영유아 간의 놀이 상호작용 활동에 관한 연구들(Y. H. Kim, 1998; Ko \& Lee, 2010; J.-Y. Kwon et al., 2015; Nam, 2006; S. Park \& Lee, 2013)은 주로 양적 연구에 집 중되어 있고, 이러한 연구들은 대부분 영유아기 자녀의 성장 발달을 위한 부모의 역할과 태도에 초점을 맞추고 있다(H.-K. Kwon, 2009; Nam, 2006; S. Park \& Lee, 2013). 그렇다 보니 정 작 아버지들이 자녀와의 신체 놀이 상호작용을 통해 어떤 경 험을 하며, 그 경험이 자신의 성장에 어떻게 관련되는지에 초 점을 맞춘 연구는 그 중요성에 비해 많이 부족한 편이다.

한 사람의 남성은 자녀의 출생과 함께 자연적으로 생물학 적 의미의 아버지가 된다. 그러나 문화적·정서적 의미의 아버 지는 자녀의 탄생과 함께 저절로 되는 것이 결코 아니다. 이른 바 부성 정체성이라는 것은 아버지와 자녀 사이의 상호작용 을 통해 형성되며 발전해가는 것으로, 본 연구에서는 이를 '아 버지 되기'라 부를 것이다. 자녀와의 발전적인 관계를 형성하 고 유지하기 위한 노력, 즉 아버지 되기 과정이 성공적으로 진 행되면 자녀의 성장 발달에 긍정적 영향을 미칠 뿐만 아니라, 아버지의 자아 존중감 역시 향상된다. 아버지 자신의 삶의 질 을 향상시켜 성인기로의 전이에 중요한 토대가 된다는 것이다 (Moon, Lee, \& Park, 2009).

이처럼 자녀와의 신체동작 놀이는 자녀의 성장과 발전이라 
는 측면 외에도 아버지의 성장을 촉진하는 수단으로써 매우 중요하다. 그러므로 아버지와 영아기 자녀 간의 신체동작 놀 이 과정에서 아버지는 어떤 경험을 하며 그 경험이 갖는 의미 는 무엇인지 밝히는 것은 자녀양육에서 아버지의 역할과 비중 이 강조되는 현실에서 매우 중요하고도 시의 적절한 연구라 할 수 있다.

이러한 맥락에서 본 연구는 자녀 양육 실제에 있어 영아기 자녀를 둔 아버지들의 영아기 자녀와의 신체동작 놀이 경험과 그 과정 속의 즐거움, 만족감, 어려움, 삶의 변화와 성장, 진정 한 아버지로 거듭나기 위한 노력의 과정 등을 탐색하고 이해하 는 데 목적을 두고자 한다. 이를 위하여 부모 참여 신체동작 놀 이 프로그램을 실시하고 있는 영유아놀이 교육 기관을 연구 현 장으로 선정하였다. 이러한 놀이 교육 기관들에서는 가정에서 보다 대·소근육을 다양하게 움직이며 신체동작 놀이를 마음껏 즐길 수 있도록 구성된 놀이실을 구비하고 있어 자녀와의 놀 이에 대한 아버지의 경험을 생생하게 탐색할 수 있다는 장점이 있다. 이곳에서 아버지들은 영아기 자녀와 기고, 걷고, 달리고, 오르고, 미끄러지고, 터널을 통과하는 등 몸의 움직임, 즉 동작 을 매개로한 놀이 상호작용 경험을 구성하고, 그 경험은 다시 아버지 되기의 경험으로 이어질 것이다. 이에 본 연구는 신체 동작 놀이 교육 기관에 참여하는 영아기 자녀를 둔 아버지들의 경험 실체를 신체동작 놀이에 대한 맥락적 측면에서 생생히 드 러내어, 그들의 눈으로 조망하고, 의미를 탐구해 보고자 한다. 이는 아버지의 역할과 태도, 그로 인한 영향만을 강조하는 기 존 실증적 연구의 한계를 넘어선 의미 있는 연구가 될 것이다. 또한 신체동작 놀이의 긍정적 가치와 영향을 재확인하는 것을 넘어 올바른 아버지 양육 참여 방법을 모색하게 될 것이다. 이 러한 논의는 아버지들의 목소리를 반영한 아버지 교육 프로그 램 개발의 기초 자료로도 활용될 수 있을 것이다.

\section{연구문제 1}

아버지와 영아기 자녀와의 신체동작 놀이는 어떠한 양상으로 나타나는가?

\section{연구문제 2}

영아기 자녀와의 신체동작 놀이가 아버지 되기 경험에 주는 의미는 무엇인가?

$$
\text { 용어 정의 }
$$

본 연구에서 사용되는 용어의 의미는 다음과 같다.
첫째, '영아기 자녀를 둔 아버지'는 출생에서 36개월까지의 영아를 둔 아버지를 의미한다. 영유아보육법(2011. 6. 7.) 제 2 조 1항에서는 출생에서 만6세까지를 영유아로 규정하고, 그 중 36개월 미만까지를 영아로 규정한다. 하지만 본 연구에서 는 연구 참여 현장 기관의 클래스 단계도 함께 고려하여 자발 적인 탐색 활동을 즐기고, 동작을 통한 신체 움직임이 가능한 만 3세까지의 영아로 한정한다.

둘째, '신체동작 놀이'는 삶속 생활세계를 의미 있게 하는 도구로서 타인을 포함한 환경에 반응하고 표현하는 능동적 움 직임, 즉 동작이 놀이의 속성 중 하나인 상호작용성을 바탕으 로 구성하는 신체 놀이 형태를 의미한다(Y. Park, 2013). 본 연 구는 기어가고, 매달리고, 오르고, 미끄러지고, 조작하는 동작 들이 단순히 영아만의 활동에 머무르는 것이 아니라, 아버지 와의 신체 접촉과 미숙한 언어표현력을 지닌 영아들의 비언어 적 의사소통 수단인 동작을 동반한다는 사실에 주목한다. 결 국 기존의 용어로는 신체의 움직임과 그 상호작용의 중요성을 적절하게 담아내지 못한다는 문제가 발생하기에 본 연구에서 는 신체동작 놀이라는 용어를 사용하고자 한다.

셋째, 현대 철학에서는 인간의 몸을 단순히 물질적 실체로 만 이해하지 않는다. Merleau-Ponty (1976/2002)는 몸이 인식 의 근원이며 지식과 경험의 원천이라고 주장한다. 즉 몸은 신 체 각 부분들의 총합이상이며, 정신과 육체가 분리되기 이전 의 통합적인 생명원리로서의 ‘몸’이다(H. Lee, 2009). 따라서 주체로서 몸은 지각을 통해 다른 대상과 직접적인 관계를 맺 는 유일한 통로이며, 정신, 이성, 마음, 의식 등은 신체화된 경 험(embodied experience)으로 나타날 때 제 기능을 수행하는 것 이다. 본 연구에서는 신체동작 놀이를 매개로 한 영아기 자녀 와 아버지의 활동을 몸의 현상으로 이해한다. 아버지와 자녀 간의 상호적 관계 속에서 신체동작 놀이가 미치는 영향은 단 순히 육체적 영역에 머무르지 않고 서로의 인식적, 정서적 영 역에까지 영향을 주고받기 때문이다. 이에 전술한 내용으로 해석될 경우, 신체가 아닌 몸이라는 용어를 사용한다. 다만, 놀 이의 영향력을 단순히 육체적 영역에 제한하여 의미하고자 할 때는 '신체’라는 용어를 사용할 것이다.

\section{Methods}

\section{연구 참여자}

본 연구는 아버지들의 대표적인 놀이 형태인 신체동작 놀이가 
Table 1

General Background of Research Participants

\begin{tabular}{|c|c|c|c|c|c|c|c|c|}
\hline $\begin{array}{c}\text { Research } \\
\text { participant }\end{array}$ & $\begin{array}{l}\text { Age } \\
\text { (years) }\end{array}$ & Occupation & $\begin{array}{l}\text { Academic } \\
\text { background }\end{array}$ & $\begin{array}{l}\text { Wife's age } \\
\text { (years) }\end{array}$ & $\begin{array}{l}\text { Wife's } \\
\text { occupation }\end{array}$ & $\begin{array}{l}\text { Child's age } \\
\text { (months) }\end{array}$ & $\begin{array}{l}\text { Child's } \\
\text { sex }\end{array}$ & Notes \\
\hline Chang-dae's father & 46 & Pastor & Graduate school degree & 36 & Teacher & 8 & Male & $\begin{array}{l}\text { Mother-in law providing } \\
\text { support in child care }\end{array}$ \\
\hline Sae-bom's father & 42 & $\begin{array}{l}\text { A faculty member } \\
\text { at a university }\end{array}$ & Graduate school degree & 38 & Office worker & 24 & Male & $\begin{array}{l}\text { Mother providing } \\
\text { support in child care }\end{array}$ \\
\hline Sang-jin's father & 37 & 0ffice worker & Under graduate degree & 39 & Office worker & 9 & Male & $\begin{array}{l}\text { Baby sitter supports for } \\
\text { child }\end{array}$ \\
\hline Sang-mi's father & 37 & 0ffice worker & Under graduate degree & 32 & House wife & 31 & Female & \\
\hline A-yeong's father & 33 & 0ffice worker & Under graduate degree & 32 & House wife & 35 & Female & $\begin{array}{l}\text { Wife has a job as a } \\
\text { kindergarten teacher }\end{array}$ \\
\hline Eun-jeong's father & 33 & Researcher & Under graduate degree & 33 & House wife & 14 & Female & \\
\hline
\end{tabular}

Note. the study participants and their children were marked under assumed names.

보다 생생히 드러나는 현장에서의 영아기 자녀와의 신체동작 놀이 경험과 그 의미를 연구하고자 신체동작 놀이 프로그램을 운영하는 G 영유아 신체 놀이 교육 기관을 연구현장으로 선 정하였다. 사전 영아 대상 신체동작 놀이 교육 기관 조사결과, 'G 기관'은 본 연구 주제에 맞게 영아와 부모 참여 신체동작 놀 이 프로그램을 40 년 넘게 국내외에 700 여 개의 기관에서 체계 적으로 운영하고 있다. 무엇보다 넓고 안전한 놀이실에 미국 기구디자이너인 Beckwith (S. Lee, 2007)가 제작한 신체동작 놀 이기구 외에 놀잇감들이 잘 구비되어 있어 제약 없이 아버지 들이 영아기 자녀와 마음껏 신체동작 놀이를 하는 생생한 현 상을 관찰할 수 있다는 장점이 있다.

또한 본 연구는 아버지들의 영아기 자녀와의 신체동작 놀 이 경험이 한 사람의 남성에서 '아버지로의 전이' 경험에 어떤 의미가 있는지 탐구하는 것에 주목하고 있다. 따라서 연구 참 여자로서 연구 주제 수행 방향에 맞는 아버지들을 모집하기 위해 IRB 승인 시점부터 일주일동안 연구 현장이 위치한 서울 특별시 G지역 인터넷 맘카페인, 'S구 엄마모임'에 G 기관의 신 체동작 놀이 프로그램에 참여하는 영아기 첫 자녀를 둔 아버 지들을 대상으로 공개 모집하였다. 연구자는 공지문을 보고 신청한 아버지들 가운데 목적적 표집에 따라 질적 연구 수행 을 위한 중요한 조건으로, 본 연구 주제에 대한 자신의 경험을 언어적으로 풍부하게 제공 가능하고, 연구자가 적절하고 많 은 자료를 얻을 수 있는 여건과 조건이 가능한 아버지들을 신 청 접수된 이메일 내용으로 1차적으로 선별하였다. 그런 다음, 선별된 참여자들을 대상으로 전화 통화 인터뷰로 최종 6명의 연구 참여자들을 선정하였다. 연구 참여자들의 일반적 배경은
Table 1 과 같다.

창대아버지는 교회목사이며, 맞벌이 부모님 슬하의 2 남 2 녀 중 장남으로 태어났다. 가정적이셨던 아버지의 영향으로 가정에서 남자와 여자, 남편과 아내의 구분에 따른 역할분담 은 불필요한 경계라 생각하고 있다. 바쁜 목회에도 짬이 날 때 마다 언제든 자녀와 놀아주는 것은 당연한 그의 일과이다. 그 에게 자녀는 결혼 후 오랜 기다림과 기도 속에 생긴 태의 열매 라 애틋함과 소중한 마음이 크다. 또한 진정한 하나님의 축복 이자, 성경말씀처럼 부모의 끝없는 사랑을 받아야 하는 존재 라고 생각한다.

새봄아버지는 대학교직원이며, 아이들을 좋아해서 교회학 교 영아부 교사로 오랫동안 봉사하였고, 결혼 전에는 누이의 조카를 어머니가 대리 양육하였기 때문에 일찍부터 영아와 생 활하고 놀이하는 것만큼은 자신 있어 했다. 하지만 결혼 후 태 어난 영아기 자녀 양육은 자신감만으로 되는 것이 아님을 깨 닫게 되었다. 2 년 가까운 모유수유로 아직까지도 아내에게 유 독 집착하는 자녀의 까다로운 기질을 감당하는 데 한계를 느 끼고 있지만, 그럼에도 자녀 양육을 위해 끊임없이 노력하고 있다.

상진 아버지는 중소기업 영업팀장이며, 2살 연상인 아내와 4 년 전에 결혼하였다. 노산의 상황에서 자연분만한 아내의 남 다른 양육관과 교육관이 과잉양육으로 이어질까 우려하고 있 다. 또 권위주의적인 부모님 밑에서 성장기를 보내며, 학업으 로 인해 운동선수의 꿈을 포기한 심리적 상처를 갖고 있다. 자 신의 성장과정에서 겪은 정서적 아픔을 자녀에게 만큼은 물려 주고 싶지 않기에, 언제나 자녀와 적극적으로 신체 놀이를 하 
고 있다. 무엇보다 자녀 출생 이후부터 그에게 삶의 중심과 목 적은 자녀에게 집중되고 있다.

상미아버지는 직장생활 10 년차 회사원이다. 전라도 토박이 에다 남자형제만 있었던 유년시절의 성장배경, 남학생들로만 구성된 공대졸업생, 여직원 없는 건축사무실 근무경험은 무뚝 뚝한 성격에 가부장적 아버지로부터 영향 받은 보수적 사고까 지 더해져 현재 자신의 성격을 완성시켰다. 특히, 유년기 단 한 번도 놀아 주신 적 없는 아버지의 영향은 무엇보다 크다. 이와 같은 성장 배경과 특히, 원 가족 아버지와의 전무한 놀이 경험, 전업주부 아내와 딸 사이의 강력한 유대관계로 인해 그는 “딸 바보 아빠'가 되기 위해서는 다른 아버지들보다 더 많은 시간 과 노력이 필요하다는 것을 알고 있다.

아영아버지는 가정적이신 아버지와 다정다감하신 어머니 슬하의 둘째로 태어난 중소기업에 근무하는 직장인이다. 아내 가 전직 유치원교사여서 자녀 양육만큼은 아내의 몫으로 두고 싶었지만, 가정적이신 아버지처럼 되고 싶은 바람을 늘 갖고 있기에 자녀 양육에 적극적으로 참여하려고 노력 중이다. 아 내를 위해 육아휴직도 감행할 정도로 무엇보다 부부 간 역할 분담을 위해서 아버지의 양육참여는 반드시 필요한 부분이라 생각하고 있다.

은정아버지는 사업가 아버지를 둔 중소기업 $\mathrm{R} \& \mathrm{D}$ 실 팀장 이다. 그의 아버지는 $\mathrm{CEO}$ 여서 늘 회사일로 바쁘셨고, 기업대 표의 모습을 가정에서도 이어가셨기에 아버지에 대해서는 권 위주의적이고 엄격하셨던 기억만 현재 그에게 남아있다. 반면 그의 어머니는 아버지가 회사 일에만 신경 쓸 수 있도록 집안 일을 도맡으셨다. 따라서 가정 내 전통적인 부부 역할분담을 어린 시절부터 자연스럽게 보고배우며 자랄 수밖에 없었다. 하지만 결혼하여 자녀를 양육하면서 사회 · 문화적 변화로 가 족 내 부부 간 역할이 고정되지 않고 가족의 행복과 자녀의 성 장을 위해 변화되어야 할 부분이라 생각하고 있다.

\section{연구 절차 및 자료 수집}

본 연구의 자료 수집은 연구 참여자의 윤리적 고려를 위해 IRB 승인 시점인 2016년 9월부터 11월까지 3개월 동안 연구 자가 심층 면담과 'G 영유아 놀이 교육 기관' 영아 대상 클래스 의 참여 관찰을 실행하였다. 그 외에도 연구자의 반성적 저널 쓰기와 현장 약기를 통해서도 자료를 수집하고 검토하였다. 심층 면담은 시간적 흐름을 담아 영아기 자녀와 신체동작 놀 이를 하며 아버지로서 어떤 변화를 경험하는지 아버지 되기 과정을 생생히 드러내어 살펴보기 위해, 연구 참여자들이 참
여하는 신체동작 놀이 수업 12 주 기간을 초, 중, 후기로 나눠 각 연구 참여자별 3 회씩, 총 18 회 진행하였다. 이는 연구 참여 자의 아버지 되기 과정에서 경험의 중요한 특징을 보다 잘 기 술하는 방법이 되었다. 연구 참여자의 입장, 의견, 느낌을 자유 롭게 이야기 나눌 수 있도록 개방적 질문 형식의 비구조화된 면담으로 한 회기 당 1 시간 30 분에서 2 시간 정도로 진행하였 다. 면담 일정은 연구 참여자가 가능한 시간에 잡았고, 영아기 자녀와의 신체동작 놀이 과정에서의 아버지들의 생각과 느낌, 의견 등을 좀 더 생생히 듣기 위해 되도록 아버지들이 자녀와 의 놀이 교육 기관 수업이 끝난 다음, 연구자의 참여 관찰 후에 바로 이어서 면담을 진행하였다. 그렇지 않은 경우에는 평일 직장 퇴근 후 연구 참여자의 집 또는 직장 근처 카페에서 면담 을 진행하였다. 모든 면담은 연구 참여자의 동의를 받아 녹음 기로 녹음하였고, 녹음자료는 당일에 바로 전사하였다.

참여 관찰은 연구 참여자들이 영아기 자녀와 신체동작 놀 이 프로그램에 참여하는 $\mathrm{G}$ 영유아 놀이 교육 기관 클래스에 연구자가 놀이 보조자로 참여하여 연구 참여자의 신체동작 놀 이 현상을 그대로 관찰하였다. 아버지와 영아기 자녀 간의 안 고, 오르고 매달리고, 기고, 걷고, 달리고 등의 신체동작 놀이 상황과 상호작용 과정, 감정 표현 모습까지 담긴 신체동작 놀 이의 실제를 연구자의 눈으로 직접 관찰하는 것은 심층 면담 을 통해 알 수 없는 부분까지 생생히 전달해주는 역할을 하였 다. 뿐만 아니라 연구 참여자가 신체동작 놀이 경험 중 설명하 기 어려운 부분에 대해서도 실제 상황으로 설명되어지는 유 용한 자료가 되었다. 심층 면담과 마찬가지로 아버지로서 변 화 과정을 살펴보기 위해 연구 참여자들이 참여하는 놀이 수 업 12 주 기간을 초, 중, 후기로 나눠 총 13 회의 참여 관찰을 하 였다. 연구 참여자들과 기관 원장, 클래스 담임교사, 회원 동의 하에 중요 장면은 참여자의 심리적 부담을 주지 않고 자연스 런 동작 놀이 현상 그대로 기록하기 위해 사진촬영을 하였다. 참여 관찰 내용은 당시의 기억을 생생히 되살리기 위해 사진 을 첨부하여 관찰 당일에 바로 참여 관찰 일지에 기록하였다.

또한 반성적 저널 쓰기를 통해 심층 면담과 참여 관찰을 하 는 과정에서의 연구자의 생각과 의견, 영아기 자녀와 아버지 의 신체동작 놀이 과정, 아버지의 상호작용 방법과 그에 대한 자녀의 반응, 아버지의 태도에서 나타난 특별한 부분, 지난 면 담 및 관찰 내용과의 차이점, 변화된 부분 등에 대해 기록하였 다. 이러한 과정은 연구자가 연구 문제와 관련하여 기록하고 관찰하고 있는지를 검토하고, 연구자 또한 자녀를 양육하고 놀이 상호작용을 하는 양육자의 입장에서 아버지의 놀이 현상 을 보고 있는 것은 아닌지에 대해 스스로 질문하면서 반성하 
는 계기를 갖게 하였다. 무엇보다 본 연구가 객관적 관점을 가 질 수 있도록 하는 중요한 자료로 활용되었다. 본 연구가 질적 연구로서 자료 수집의 편향성을 갖지 않도록(Wolcott, 1990) 심층 면담, 참여 관찰, 반성적 저널쓰기 외에도 연구자의 현장 노트뿐만 아니라 연구 참여자의 카톡 사진, 개인 조사서 등의 다양한 자료도 수집하였다.

\section{자료분석}

연구자는 수집된 연구 참여자 아버지들과의 심층 면담 전사본 과 G 영유아 놀이 교육 기관에서의 아버지들의 영아기 자녀와 의 신체동작 놀이 현상을 직접 참여 관찰하며 얻은 사진 자료 가 포함된 참여 관찰 일지, 연구자의 반성적 저널, 그 외의 현 장 노트 등을 토대로 하여 자료를 분석하였다. 여러 차례의 정 독을 통해 연구문제와 관련된 부분을 숙지, 정리하고 정리된 자료는 연구 참여자의 의미를 중심으로 분류하는 에믹 코딩 (emic coding)과 연구문제에 대한 답이 될 내용을 찾아 구조화 하는 구조 코딩(structural coding)을 통해 자료를 분석하였다. 1 차적으로 원자료를 반복적으로 읽으면서 자료의 의미나 요지 가 잘 드러나 있는 문장에 줄을 긋는 세그멘팅(segmenting)과 관련된 내용을 하나로 묶어서 명칭을 부여하며 주제어를 정리 하였다. 그 결과 연구문제 1,2 에 대해 25 개의 초기 코드를 도 출할 수 있었다. 2 차적으로 에믹 코딩을 통해 25 개의 초기 코 드는 8 개의 범주로 통합되었고, 최종 2 개의 상위 범주로 묶였 다. 이처럼 유형에 따라 분류, 목록화한 뒤 자료를 여러 번 정 독하고 예비 범주를 조정한 다음, 조정된 범주에 따라 자료를 분석하였다.

본 연구는 연구의 타당성과 신뢰성을 확보하기 위해 첫째, 질적 연구의 일반적 평가 방법인 삼각 검증법을 실시하였다. 유아동작 놀이 관련 논문을 학술지에 발표한 박사수료 연구자 의 조언을 구하고, 무엇보다 연구 내용을 지도 교수와 확인하 는 과정을 거쳐 문제점을 발견하고 수정하는 기회를 가지면 서 내용에 대한 타당도를 검증 받았다. 이러한 과정은 본 연구 의 모든 자료들에 대한 출처의 명확성과 신빙성을 가질 수 있 도록 하였다. 둘째, 연구결과물의 적합성, 이해, 유용성의 중요 성을 높이기 위해 연구결과물을 참여자에게 알려 검증을 받 는 구성원 검토 작업을 하였다. 셋째, 반성적 저널을 작성하여 비판적으로 사고하고 연구자가 가질 수 있는 편견을 감시하고 통제하기를 시도하였다.

\section{Results}

\section{아버지와 영아기 자녀와의 신체동작 놀이 양상}

현대사회에서는 사회 · 문화적 변화에 따라 '프렌디', '플레디' 라는 신조어가 생길 정도로 자녀의 놀이 파트너로서 아버지 의 역할이 강조되고 있다. 실제로 영아기 자녀를 둔 아버지 들은 어머니의 돌봄과 관련된 일반적인 양육참여보다 놀이 상황과 관련된 상호작용적인 양육참여를 더 많이 하게 되는 데, 아버지들은 어머니와 달리 신체적인 놀이 위주로 한다 (Capuozzo, Sheppard, \& Uba, 2010). 특히, 신체동작 놀이는 몸 의 움직임으로 이뤄지는 데, 몸은 경험을 확장하고 신체화된 지각(embodied perception)을 통해 주변을 탐색하며 대상과 관 계를 형성하는 상호작용의 특징을 가지게 된다(Merleau-Ponty, 1976/2002). 본 연구에서 아버지들의 영아기 자녀와의 신체동 작 놀이는 첫째, 신체에 갇힌 놀이, 둘째, 남자-여자 놀이에 갇 힌 놀이, 셋째, 세대에 걸쳐 전이된 놀이, 넷째, 버거운 놀이로 분석되었다.

\section{신체에 갇힌 놀이}

영아기 자녀를 둔 아버지들은 자녀와의 놀이 상호작용 과정에 서 어머니처럼 노래 부르기나 놀잇감을 사용하여 놀이하기보 다는 아기를 안거나 들어 올리는 것과 같은 신체 움직임을 활 용한 놀이를 시도한다(Lamb, 2010). 신체 움직임은 몸을 매개 로하여 이뤄지며, 아버지와 영아기 자녀와의 신체동작 놀이는 몸으로 주변세계를 탐색하고, 몸의 신체화된 지각(embodied perception)으로 경험을 축적하고, 사물과 세계뿐만 아니라 사 물과 대상과의 관계를 배워가는 중요한 과정이 된다.

하지만 신체동작 놀이를 처음 시작하는 과정에서 연구 참 여자 아버지들은 영아기 자녀의 발달 특징에 대한 이해 및 자 녀와 몸으로 하는 놀이 상호작용에 대한 경험부족으로 몸의 움직임을 통해 대상과의 상호작용이 이뤄지는 신체동작 놀이 보다는 육체적 의미의 신체에만 중점을 두고 놀이하였다. 그 결과 신체동작 놀이의 범위와 방법들이 제한적이었으며, 영아 의 신체적 본능과 욕구 충족에 머무르고 말았다. 또한 아버지 들은 현재까지도 선호하거나 아동기에 충족되지 못한 스포츠 활동에 대한 대체적 욕구실현으로써 신체동작 놀이를 하는 양 상이 드러났다. 
저는 신체 놀이를 많이 하고 싶긴 한데 $\cdots$ 아이를 막 물구 나무 세우고 들었다 놨다 하고 '체육' 하는 것 같은 그런 것들은 아직 $\cdots$ 좀 그렇긴 해요. 그래서 아이를 조심스럽 게 들긴 하죠. 아직 아기라서 거칠게 신체 놀이 하는 건 왠지 위험할 것 같기도 하고... 좀 그래요.

(심층 면담, 창대아버지, 2016.9. 10.)

아이가 신체로 노는 것은 저에게 꼭 와요. 역동적인 것을 또 본능적인 욕구가 생길 때, 그것을 스스로 만족하기 위 해서는 엄마라는 세상보다는 아빠라는 세상이 훨씬 더 재밌고, 용이하고 또 자기도 더 만족하게 되고 그래서 더 저를 찾고 그래요. 그러니까 저도 더 그런 욕구를 충족시 켜 주고 싶은 것일 수도 있어요. 아이가 원하니까. 좋아 하니까.

(심층 면담, 새봄아버지, 2016. 10. 7.)



Figure 1. Chang-dae's father does not know how to move; he stops and looks at Chang-dae's mother. Participation observation Chang-dae's father, September 13, 2016.

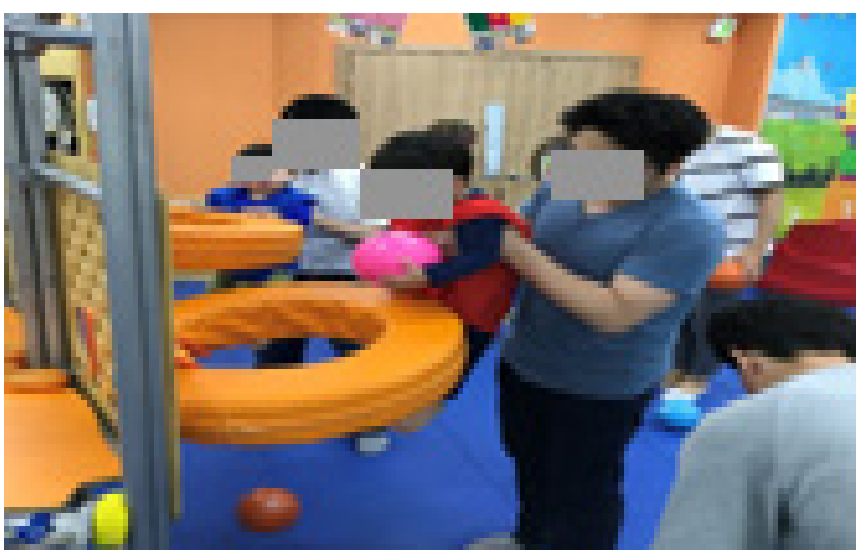

Figure 3. Sae-bom's father plays with a ball like in a basket ball game. Participation observation Sae-bom's father, October 7, 2016.
제가 상미가 GOO에서 그냥 심심해하는 것 같을 때, 아 니면 퇴근하고 집에 돌아와서 제 품에 달려오면 번쩍 들 어서 위로 높이 올려주거든요. 그것을 엄청 좋아해서 자 꾸 해달라고 해요. 근데, 그렇게 겨드랑이를 잡고 위로 높이 올릴 때 아이가 쾌감, 카타르시스를 느끼는 것 같 아요. 그래서 상미는 그걸 해 줄때마다 더 높이 올려달라 고 하고, 또 해달라고 하고 그래요.

(심층 면담, 상미아버지, 2016. 10.8.)

아이랑 놀다보면 지금 움직임이 서툰데도 공을 발로 찬 다거나, 커다란 통 안에 공을 두 팔로 넣기라도 하면 요 녀석이랑 조만간 축구나 농구도 할 수 있겠다는 생각을 하게 돼요. 그래서 몸으로 더 놀아주고 싶기도 하고요. 사실 $\cdots$ 아빠들은 그런 로망이 있거든요. 이 다음에 아들 이랑 농구도 축구도 하고 싶고, 야구도 하고 싶고. 뮈...

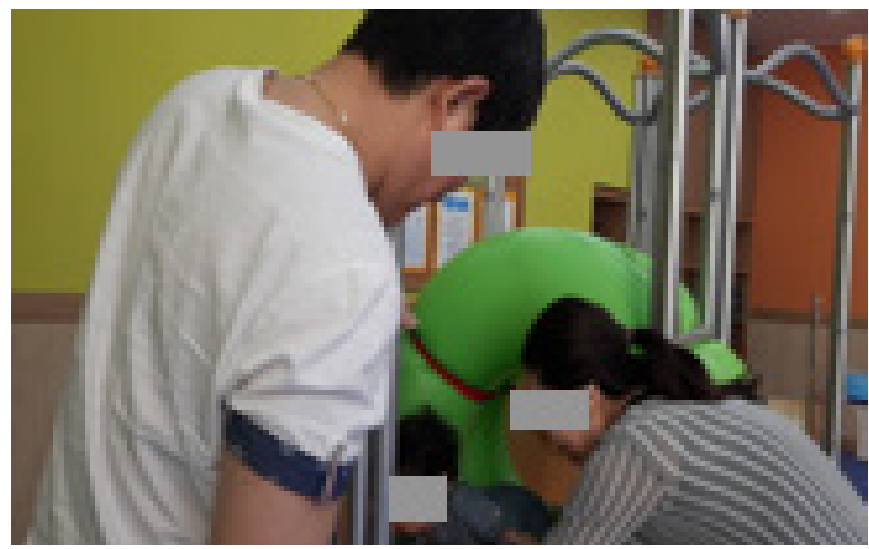

Figure 2. Sang-jin's father does not know how to play well; he could only looks at Sang-jin's mother and Sang-jin. Participation observation Sang-jin's father, September 10, 2016.

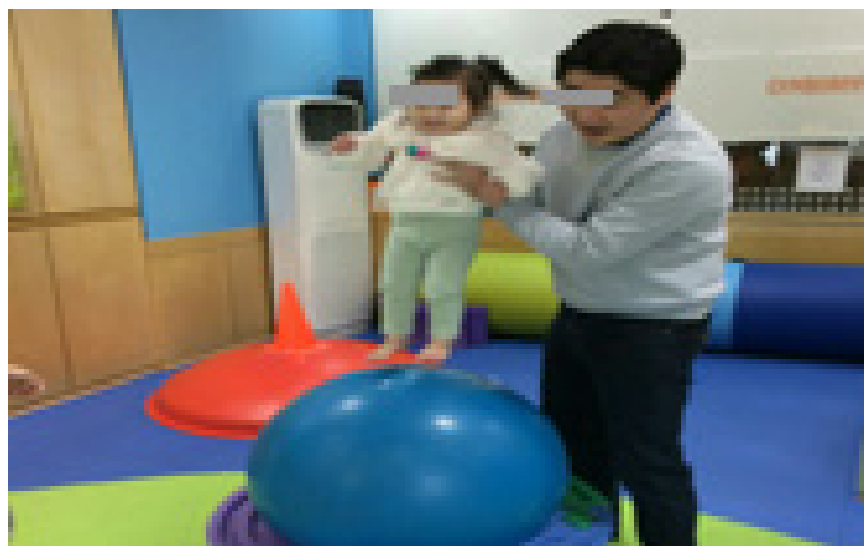

Figure 4. Sang-mi's father starts a jumping ball game to exhaust Sang-mi's surplus energy. Participation observation Sang-mi's father, October 22, 2016. 
지금 이런 신체 놀이들이 결국 나중에 그런 스포츠를 잘 하기 위한 준비 단계도 될 수 있잖아요.

(심층 면담, 새봄아버지, 2016.9. 24.)

위의 사례들 가운데 창대아버지의 심층 면담을 통해 알 수 있 듯이 연구 참여자 아버지들은 몸을 매개로 한 상호작용과 탐 색으로 이뤄지는 신체동작 놀이의 개념을 '육체' 또는 체육에 국한시켜 신체의 움직임만 주어지면 신체동작 놀이라 생각하 고 있었다. 그렇다보니 Figure 1 참여 관찰의 창대아버지처럼 다양한 신체동작의 범위와 의미의 이해부족으로 다 같이 어울 려 상호작용하는 동작놀이에서 뒤처지기도 하고, Figure 2 참 여 관찰의 상진아버지처럼 눈 맞춤과 교감이 있는 영아 신체 동작 놀이가 제대로 이뤄지지 않아 아내의 놀이 개입이 발생 하는 경우도 있었다. 이처럼 영아기 자녀와 신체동작 놀이를 처음 하는 아버지들의 놀이는 신체에만 집중된 나머지 몸이라 는 매개체의 상호작용적 의미를 배제한 놀이로서, 움직임이 미숙한 영아기 자녀의 발달과도 연계되어 놀이의 제약과 한계 성을 드러냈다.

반면 전술한 바처럼 아버지들의 신체동작 놀이가 신체에 만 집중된 한계에도 불구하고 새봄아버지의 첫 번째 심층 면 담과 Figure 4 참여 관찰의 상미아버지 사례를 통해 영아기 자 녀들은 스스로 자신의 신체적 본능과 욕구 충족을 위해 아버 지의 신체동작 놀이를 요구한다는 것을 알 수 있다. 따라서 아 버지들은 자녀의 요구에 반응하기 위해서 신체에 축적된 자녀 의 잉여 에너지가 소진 될 때까지 놀이를 지속시킴으로써 자 녀에게 만족감을 주고자 하였다. 결국 상미아버지의 이야기처 럼 그러한 만족감으로 인해 영아기 자녀 스스로 희열과 쾌감 충족을 위해 찾게 되는 놀이가 바로, 아버지들의 놀이라는 인 식으로까지 이어졌다. 뿐만 아니라 Figure 3 참여 관찰에서도 볼 수 있듯이 새봄아버지는 단순히 골대에 공을 넣는 활동을 ‘농구’라는 스포츠와 연관 짓고, 자녀의 신체동작이 미숙하더 라도 작은 반응 하나하나에 스포츠 활동으로서 의미를 부여하 였다. 이러한 놀이 양상은 결국, 자녀가 앞으로 신체동작 놀이 에 익숙해지면 자신이 좋아하는 축구, 야구, 농구와 같은 스포 츠 활동을 반드시 할 수 있을 것이라는 기대감마저 갖게 한다 는 것을 '아빠들의 로망'이라고 표현한 새봄아버지의 두 번째 심층 면담을 통해서 더욱 알 수 있다.

$$
\text { ‘남자 · 여자 놀이’에 갇힌 놀이 }
$$

자녀 양육에 있어서 아버지 역할에 대한 최근 연구들(S.-Y.
Kim, 2012; J.-Y. Kwon et al., 2015)에서는 아버지와 자녀 간에 이뤄지는 보다 적극적이고 애정적인 놀이 상호작용에 대해 강 조하고 있다(Oh et al., 2000).

하지만 본 연구에서는 부모와 영아기 자녀와의 놀이가 서 론에서 밝힌 아버지의 동적 놀이, 어머니의 정적 놀이라는 차 이에 앞서 남성과 여성이라는 성역할에 따른 놀이 역할 분담 이 이뤄지고 있었다. 즉 영아기 자녀와의 놀이 상호작용 과정 에서 아버지와 어머니의 놀이가 자연스럽게 차이를 나타내는 것이 아니라, 놀이 시작 전부터 남성 또는 여성 부모의 놀이 역 할을 구분 지으면서 놀이 방법 자체를 한정짓는 양상이 나타 났다. 또한 아버지들은 신체동작 놀이에 ‘힘 있는 남성’으로서 갖게 되는 놀이 강점과 특별함을 부여하였고, 때로는 자신들 의 놀이를 어머니의 놀이보다 우위에 두기도 하였다. 반면 어 머니들은 돌봄 중심의 양육과정이 반영된 정적 놀이만을 영아 기 자녀와 자신이 할 수 있는 놀이 상호작용으로 제한하였다. 결국 부모의 놀이에서도 성역할이 고착화되어 있었다.

아빠들은 신체로만 놀아주려고 하는 경향이 강하죠. 힘도 아빠가 훨씬 세고, 뭔가 역동적으로 노는 건 당연히 아빠가 하는 게 낫죠. 그런데 그런 것들이 그냥 한다기보다 엄마와 의 차별성을 두기 위한 방법일 수도 있어요. 사실 아이도 엄 마랑 맨날 하던 거는 저랑 할 때 재미없어하거든요. 그렇다 보니 엄마와 다르게 몸으로 신나게 놀게 되면 아이가 뭔가 특별하게 생각하죠. 엄마랑 노는 것은 일상인 거예요. 저의 놀이는 특별함이 있는 거고. 그런 신체 놀이가 결국엔 아이 와 친해지면서 아이에게 점수를 딸 수 있는 유일한 역전 의 기회까지 되더라고요.

(심층 면담, 아영아버지, 2016. 10. 1.)

엄마 놀이는 좀 질리고, 하루 종일 같이 놀이주기도 하니 $\cdots$ 동화책 읽어주면서 말로 놀아주잖아요. 하지만 아빠는 다 르죠. 일주일에 한번 주말 또는 저녁에 퇴근하고 놀아주게 되는데, 희소성도 커지고, 무엇보다 재밌잖아요. 임팩트가 있죠. 엄마는 아무래도 운동신경도 아빠보다 떨어지고 한 계가 있거든요. 신체 놀이에는 $\cdots$ 와이프는 신체 놀이하다 빨리 지쳐하고, 동작도 크지 않고 $\cdots$ 그러니 재미가 없죠. 그 래서 은정이와 몸으로 동작을 크게 하면서 노는 것이 아빠

\section{로서 점수 따기에 딱이에요.}

(심층 면담, 은정아버지, 2016. 9. 28.)

와이프는 아예 몸으로 놀이하는 것 자체를 제가 해야 한다 
고 $\cdots$ 몸으로 놀이하는 것을 상진이가 너무 좋아하니 저보 고 놀아주라고. '강요 아닌 강요'를 하기도 하죠. 본인은 저 처럼 놀 수 없다나? 상진이가 재미없어 한다고... 무 와이프 가 저보다 힘이 없고, 상진이도 저랑 몸으로 놀 때 더 많이 좋아하니 아이가 느끼는 것도 다를 테고... 뮈... 엄마보다 더 재밌겠죠.

(심층 면담, 상진아버지, 2016. 9. 20.)

항상 와이프는 상미랑 잘 놀다가도 상미가 문가 뛰거나 높 이 안아달라고 하는 타이밍이 오면 그건 아빠가 더 잘해. 그 러면서 저에게 쓱 넘기죠. 상미와 놀아주다가도 딱 힘 있게 보조해야 하거나, 힘을 많이 써야 하는 활동이나, 체조시간 되면 꼭 아빠 손잡고 하라고 아예 아이한테 대놓고 말해요. 그러고 본인은 상미가 즐겁게 저랑 놀이하는 것을 지켜보 기만 하죠.

(심층 면담, 상미아버지, 2016.9. 17.)

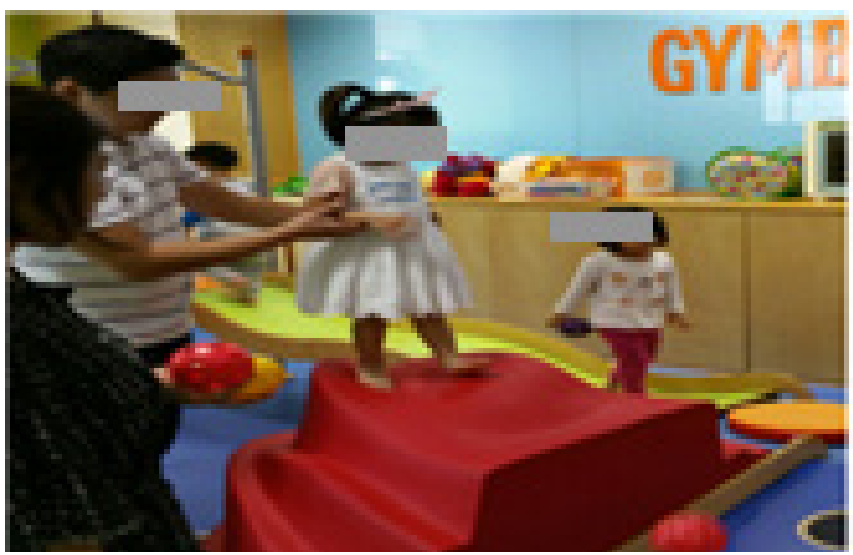

Figure 5. Sang-mi's father actively assists Sang-mi's climbing the equipment, and Sang-mi's mother looks from the side. Participation observation Sang-mi’s father, September 17, 2016.

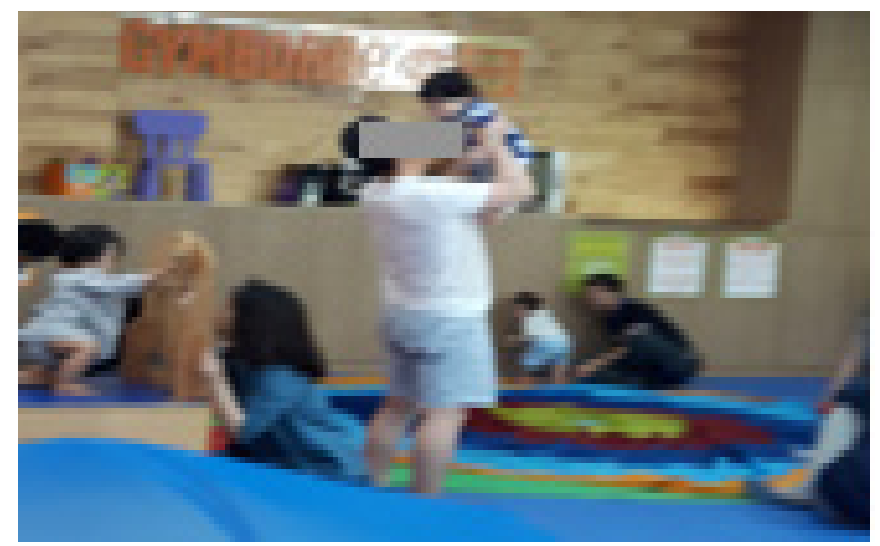

Figure 7. Sang-jin's father plays roller-coaster with Sang-jin. Participation observation Sang-jin's father, September 10, 2016.
위의 사례들 가운데 아영아버지와 은정아버지의 심층 면담에 서 아버지들은 자신들의 신체동작 놀이에 대해 '차별성', ‘특별 함, '희소성, ‘임팩트' 있는 놀이로, 어머니의 놀이에 대해 동화 구연과 같이 '언어 놀이', ‘정적 놀이'로 표현하였다. 아버지들이 이야기한 어머니의 놀이 관련 표현들은 선행연구들에서 밝힌 놀이 특성 내용과 일치한다. 또한 아버지들은 신체적 움직임과 민첩성, 지구력에서 남성보다 열세에 있는 여성의 힘 중심의 신체적 한계성을 놀이 형태 선택에서 주요 원인으로 규정하였 다. 이로 인해 자녀 또한 어머니의 제한된 놀이로 인해 즐거움 과 놀이 욕구 충족에 한계를 느끼게 된다고 하였다. 그러한 자 녀들의 반응을 보면서 아버지들은 Figure 7,8 참여 관찰에서처 럼 더욱 역동적인 신체동작 놀이에 자극을 받고 강화되어 자녀 에게 보다 잘 놀아주는 아버지로서의 역할을 수행하고 싶어 하 였다. 아영아버지와 은정아버지의 “아빠로서 점수 따기에 딱 이에요."라는 공통된 표현은 그 바람을 더욱 여실히 드러낸다.

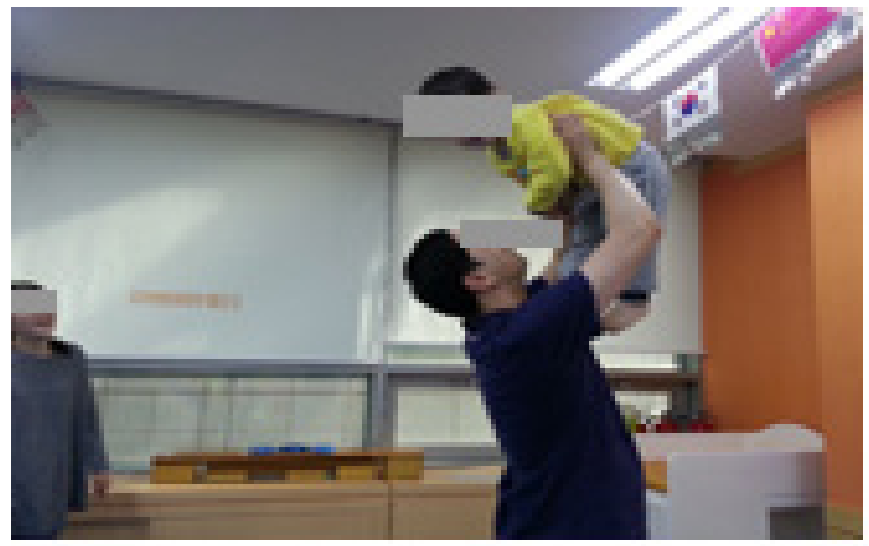

Figure 6. Sae-bom's father lifts Sae-bom high, and Sae-bom's mother looks from the side. Participation observation Sae-bom's fathers, October 7, 2016.

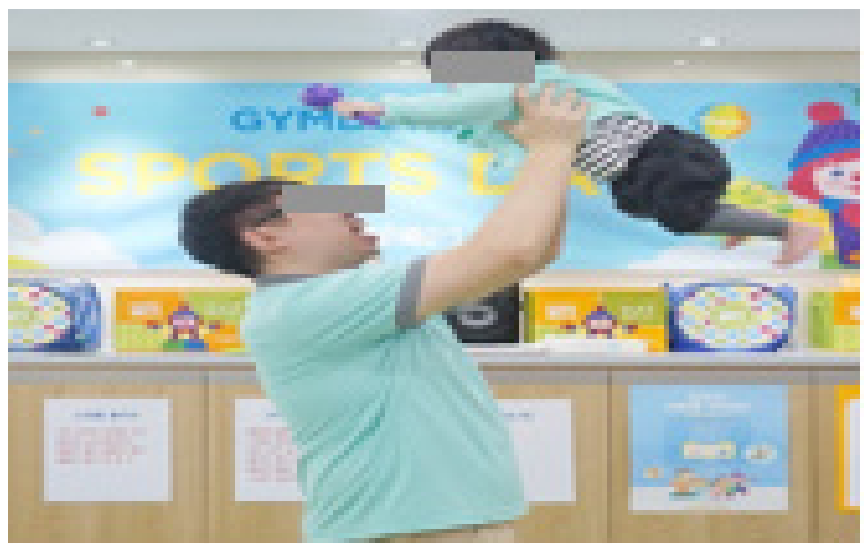

Figure 8. Eun-jeong's father lifts Eun-jeong high. Participation observation Eun-jeong's father, October 22, 2016. 
반면, 상진아버지와 상미아버지의 심층 면담에서 아버지들 은 한 결 같이 어머니들 스스로 자신의 놀이와 아버지의 놀이 를 구분 짓고, 그에 대한 역할 분담을 명확히 한다고 하였다. Figure 5, 6 참여 관찰에서 상진어머니와 새봄어머니는 공굴리 기와 같은 단순한 신체동작에서는 자녀와 놀이를 하지만, 뛰 기, 들어올리기와 같이 역동적 동작으로 놀이가 전환되면 자 연스럽게 아버지들에게로 놀이 역할전이가 이뤄졌다. 즉, 자 녀가 어떤 놀이를 하든 놀이 참여의 시작이 어머니였다 할지 라도 결국 역동적 신체동작이 요구될 경우, 연구 참여자 자녀 들의 어머니들은 놀이를 지속시키기보다 아버지인 자신에게 그 역할을 부여한다고 하였다. 이를 통해 부모-자녀 놀이 상호 작용에 있어서 어머니와 아버지의 놀이 유형 간 서로 대조되 는 특징과 놀이 참여 역할은 놀이 과정 중에서 놀이 특성과 놀 이 참여, 그에 대한 효과적 놀이 촉진, 상호작용 모색 과정에서 구분되었다고 보기 어렵다. 오히려, 자녀와의 놀이 상호작용 이전부터 어머니들의 인식 속에서 이미 힘 있는 남성과, 그렇 지 않는 여성이라는 성역할 고정관념이 반영되어 있는 것임을 알 수 있다.

\section{세대에 걸쳐 전이된 놀이}

오늘날 아버지들은 권위주의적 아버지로서 자신의 아버지를 기억한다. 특히, 원 가족 부모의 물리적·심리적 부재를 경험했 던 아버지들은 신체적.정서적으로도 자녀와의 거리감을 주는 권위주의적인 아버지의 모습이 자신에게서 재현되지 않기를 바란다(S. Kim, 2015). 그럼에도 불구하고 어린 시절 경험한 아 버지의 양육 경험은 성인이 되어 자녀를 양육할 때 많은 영향 을 주는 것으로 나타나기도 한다(Y.-D. Kim \& Lee, 2011).

연구 참여자 아버지들 또한 원 가족 부모와의 놀이 경험과 관련되어 아버지의 놀이 역할 모델이 자녀와의 신체 놀이 상 호작용에 반영되고, 아버지 역할 수행이나 아버지 상 형성과 정에 작동하여 영향을 주고 있다고 하였다. 부정적인 양육을 경험했던 아버지들은 신체동작 놀이를 통해 원 가족 아버지와 의 놀이 부재로 인한 부정적 정서 경험을 다음 세대인 자녀에 게 전이되지 않도록 노력하고 있었고, 자녀와의 신체동작 놀 이가 매개가 되어 친밀감 있는 아버지 되기 과정으로 이어질 것이라는 신념을 갖고 있었다. 반면, 원 가족 아버지와의 즐거 웠던 신체 놀이 경험을 아버지가 된 현재 자녀와의 놀이 상호 작용에 자연스럽게 반영하여 자녀와 공유하며 세대를 거듭한 즐거운 추억으로 재저장하는 경우도 있었다.
아버지가 어릴 적 신체 놀이를 잘 해주신 기억이 없어요. 제 가 그렇게 공을 좋아하는데 공 한번 가지고 저랑 놀아주신 적이 없었던 것 같아요. (중략) 제가 아버지를 통해 배운 게 없으니까... 상진이와 놀아주는 것도 모르고 어떻게 대해야 하는지도 모르고 $\cdots$ 전 저와 같은 그런 정서적 경험, 불편한 부분들이 자녀에게 대물림 될까봐… (중략) 그래서 결국 교 육방법을 배우려고 여기에도 온 거고 $\cdots$ 상진이게는 충분한 아버지와 즐거운 놀이경험이 있다라는 느낌을 주고 싶어요.

(심층 면담, 상진아버지, 2016. 9. 13.)

아버지는 공무원이셨는데, 정말 어릴 적에 저와 단 한 번도 놀아주셨던 기억이 없어요. 그래서 지금도 사실 명절에 뵈 면 서먹서먹하기도 해요. 어릴 적 아버지가 놀아주시지 않 으셨으니 친근할 리가 없죠. 몸으로 부대끼기며 놀아야 $\cdots$ 사람도 스킨십이 있어야 친해지고 그러잖아요. 그래서 아 버지와의 안 좋은 기억이 아직도 남아 있어서 그런지 지금 상미와 놀 때마다 그런 생각을 하게 되죠. 우리 상미에게는 나 같은 기억을 남겨주지 말자...

(심층 면담, 상미아버지, 2016. 9. 17.)

아버지는 다른 아버지들과 달리 무척 재밌으셨어요. 일찍 퇴근하시거나, 주말만 되면 거인잡기, 베개싸움, 묵찌빠, 방 귀뽕 놀이도 해주셨는데, 거인잡기, 베개싸움은 아영이와 지금도 많이 해요. 제가 아버지와의 놀이를 기억해서 아영 이게 해주고 싶은 것처럼 아영이도 커서 자기 아이들과 제 가 해줬던 놀이를 하면 $\cdots$ 아영이에게 저처럼 아빠와의 놀 이추억을 남겨주고 싶어요.

(심층 면담, 아영아버지, 2016. 10. 8.)

위의 사례들을 가운데 상진아버지의 심층 면담과 Figure 9 참 여 관찰에서 어린 시절 아버지와의 공놀이 경험조차 갖지 못 한 상진아버지는 그에 대한 놀이 경험 보상이라도 하듯 놀이 시간에 제시된 놀이보다는 유독 공놀이에 집착하여 신체동작 놀이를 하는 모습을 발견할 수 있었다. 이처럼 원 가족 아버지 의 놀이역할 부재는 단순히 아픈 기억으로만 남는 것을 넘어, 현재 놀이하는 아버지의 역할모델에 잔재되어 혼란과 어려움 을 겪게 하고 있었다. 하지만 연구 참여자 아버지들은 그에 대 한 극복방안이자, 원 가족 아버지의 역할모델을 답습하지 않 기 위해 부모 교육 기관을 찾게 되고, 이를 통해 놀이하는 아버 지의 역할모델을 찾아 재구성함으로써 새로운 패러다임을 형 성하고자 하였다. 반면, 상진아버지나 상미아버지의 사례들과 


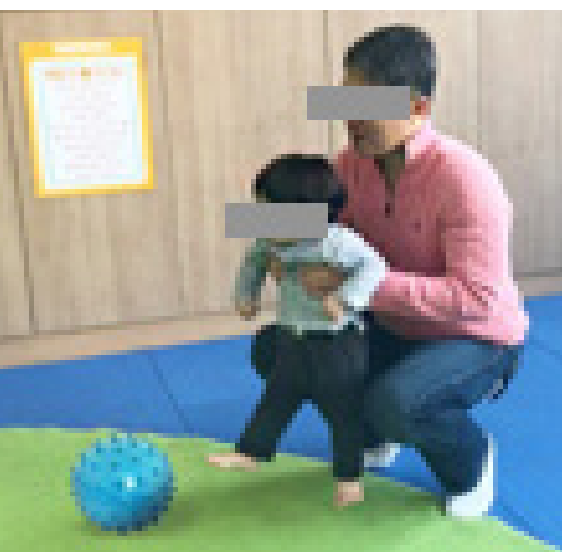

Figure 9. Sang-jin's father assists Sang-jin by raising his armpit to show him how to kick the ball. Participation observation Sang-jin's father, September 17, 2016.

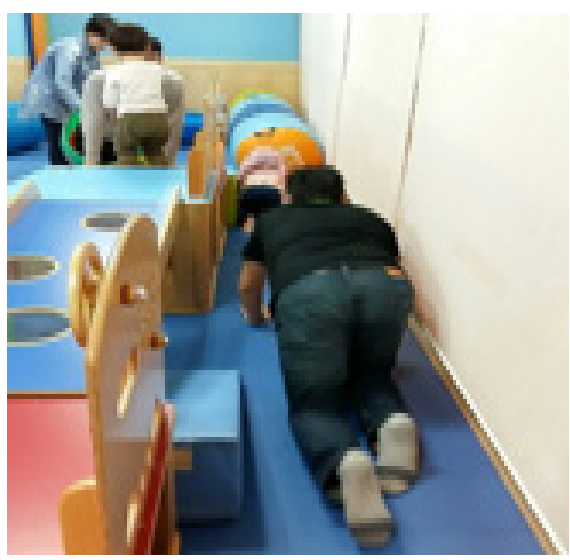

Figure 10. A-yeong's father plays a catch game that he used to enjoy with his own father when he was young. Participation observation A-yeong's father, October 1, 2016.

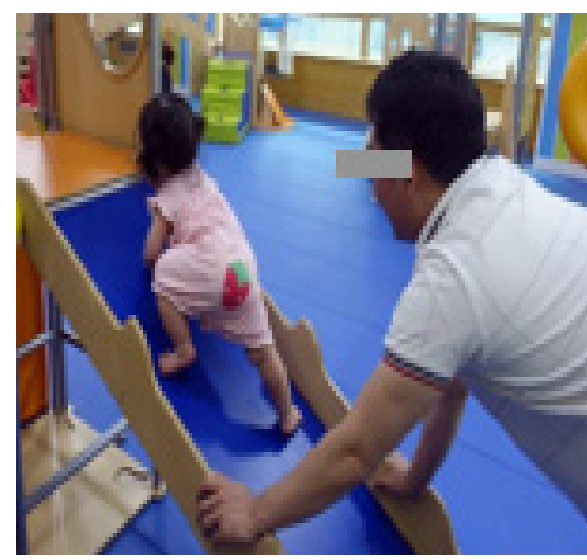

Figure 11. Eun-jeong's father plays a catch game that he used to enjoy with his own father. Participation observation Eunjeong's father, September 25, 2016.
달리, 어린 시절 프렌디 같은 원 가족 아버지와의 다양한 신체 동작 놀이 경험이 있는 연구 참여자 아버지들은 과거의 기억 으로만 남겨두지 않고, 현재 자신의 자녀와의 놀이 상호작용 에서도 의식 또는 무의식적으로 재현하는 경우도 있었다. 어 릴 적 아버지와의 신체 놀이 경험이 현재 기억 속에도 남아 있 어 놀이 시간 내내 원 가족 아버지와 즐겼던 '거인잡기' 놀이를 하는 아영아버지 심층 면담과 Figure 10,11 참여 관찰 사례는 그 예를 잘 보여준다. 결국, 원 가족 아버지와의 신체동작 놀이 경험은 즐거운 추억 또는 기억하고 싶지 않은 경험과는 상관 없이 현재의 아버지인 자신에게 신체적, 정서적으로 내재되어 자녀와의 신체동작 놀이 상호작용에 반영되고, 자신의 아버지 역할이나 좋은 아버지 상에 작동하고 있음을 알 수 있다.

\section{버거운 놀이}

첫 자녀를 둔 아버지들은 아내의 임신, 출산과정과 출산 후 양 육과정에서 수행해야하는 정확한 역할 인식 부족으로 대부분 주변 이야기를 통해 역할을 판단하게 되고, 자녀 양육의 모든 과정에 대해 신비로움과 동시에 힘들고 두렵다는 인식을 가지 고 있다(H.-S. Kim, 2005).

사회적인 프렌디, 플레디의 영향이 아니더라도 자녀와 잘 놀아주고 싶지 않은 아버지는 없을 것이다. 연구 참여자 아버 지들 또한 자신이 처한 현실과 상황 속에서 최선을 다해 양육 에 참여하고 가정과 놀이 교육 기관에서 신체동작 놀이를 하며 좋은 아버지가 되려고 노력하고 있었다. 그러나 노력만으로 되 는 것은 아니었다. 초보 양육자인 연구 참여자 아버지들은 영
아기 자녀와 신체동작 놀이를 하며 신체적·정서적으로 버거움 을 느끼고 있었다. 자신의 신체 에너지를 소진하며 놀이하는 아버지로서의 역할을 수행하는 것은 생각만큼 쉽지 않았다. 무 엇보다 영아기 자녀의 넘치는 신체에너지를 감당하기에는 아 버지들의 체력적 한계에 따른 버거움이 있었다. 또한 체력 충 전의 여유 없이 직장과 가정의 일을 병행하며 신체에너지 소진 에 이르게 되었다. 비단, 체력적 버거움만 있는 것은 아니었다. 자기중심적 사고와 소유욕이 강한 영아기 자녀와의 신체동작 놀이에서 발생하는 갈등과 문제 상황들은 양육지식과 기술, 경 험이 부족한 초보 양육자인 연구 참여자 아버지들을 힘들게 했 다. 하지만 결국 신체적 - 정서적 버거움이 신체동작 놀이 상황 안에 항상 존재함에도 불구하고 아버지들은 프렌디를 지향하 는 사회적 분위기를 외면할 수 없기에 부담감을 짊어진 채 어 떤 상황 속에서도 놀이하는 아버지가 되어야 했다.

아이는 에너지가 넘쳐서 끊임없이 놀자고 하는데 $\cdots$ 저는 체력적으로 한계가 와서 $\cdots$ 신체 놀이는 점점 아이들에게 에너지를 다운시키는 게 아니라 흥분시키는 것 같아요. 저 는 반대고 $\cdots$ 근데 아이가 다른 놀이를 할 때보다 신체 놀이 를 할 때 너무 좋아하니 저도 너무 좋고 그래서 안 놀아줄 수도 없고. (웃음) 근데, 끝없는 무한재생 놀이를 하니, 결 국, 저는 엥꼬가 되는 거죠.

(심층 면담, 창대아버지, 2016. 9. 17.)

아영이는 요즘 정말 트러블메이커 되어가고 있어요. 고집 쟁이인데다 가끔 놀다가 뭐가 맘에 안 들면 친구 얼굴을 때 
리는 경우가 있어요. 그럴 때 와이프는 엄청 혼내는데 $\cdots$ 사 실 저는 어떻게 해야 할지 모르겠어요. OOO박사가 TV에 서 말하는 것 보고 따라 해보기도 했는데 $\cdots$ 어설프기만 하 고, 괜히 잘 노는 아영이와 사이만 나빠질 것 같고...

(심층 면담, 아영아버지, 2016. 10. 1.)

회사에서 하루 종일 일하고 집에 오거나, 평일 내내 일하고 주말만 되면 아이가 저만 쳐다보고 놀아달라고 해요. 근데, 제가 널널할 때 놀아주는 게 아니라 일과 일 사이, 쉬어야할 때 놀아주는 거라, 거기다 몸으로 놀다보니 더 지칠 때가 많 이 있고 $\cdots$ 어떤 때는 마냥 소파에 누워서 쉬고 싶을 때도 있 는 데, 놀아야 되니깐 힘들죠. 방전된 몸을 충전할 틈 없이 $\cdots$ 근데 막상 아이와 놀면 좋죠.

(심층 면담, 새봄아버지, 2016. 10.8.)

TV에서 아빠들이 가정적이고 아이와 잘 놀아주고 그런 모 습들이 많이 노출되다 보니 $\cdots$ 그러면 남자들은 정말 빼도 박도 못하고 $\cdots$ 와이프도 가끔 비교하기도 하고... 사실 '아 빠 어디가?’, ‘슈퍼맨' 이런데 나오는 연예인들은 시간이 자 유롭죠. 저처럼 직장에 매여 있지는 안잖아요. (중략) 국가 가 정책적으로 받쳐주지 않으면서 매스컴으로 자꾸 아빠 들을 바꾸려하니 $\cdots$ 근데 그 분위기를 정말 무시 못 해요. (체념 섞인 목소리로) 뭐 이제는 무조건 그렇게 살아야 해 서 $\cdots$ 마초적 근성도 사라지고 $\cdots$

(심층 면담, 은정아버지, 2016.9. 28.)
위의 사례들 가운데 신체동작 놀이에서 심층 면담과 Figure 12 참여 관찰에서 반복 놀이를 끝없이 고집하는 자녀 감당의 어 려움이 있는 창대아버지, 심층 면담과 Figure 13,14 참여 관찰 에서 또래 놀이를 거부하는 떼쟁이 자녀와의 놀이 상호작용 부담을 지닌 상진아버지와 은정아버지, 심층 면담에서 친구에 게 신체적 해를 가하는 공격적 자녀 양육의 바람직한 해결법 을 찾는 아영아버지의 사례처럼 연구 참여자 아버지들은 발달 단계 상의 영아기 자녀 행동특성으로 인해 어려움을 경험하였 다. TV 프로그램 육아전문가의 의견이나 기관 프로그램의 도 움을 통해 그러한 어려움을 해결하고자 하지만 여전히 심리적 성장통을 겪고 있었다. 또한 새봄아버지의 심층 면담 사례처 럼 '체력충전을 위한 쉼’의 보장 없이 직장 업무 외에 많은 시 간을 에너지 넘치는 자녀와의 신체동작 놀이에 집중해야 하기 에 휴식의 절대적 부족함을 느낄 수밖에 없었다. 하지만 결국, 연구 참여자 아버지들은 그러한 신체적·정서적 버거움에도 불구하고 가부장적 아버지가 아닌 자녀와 잘 놀아주는 친구 같은 아버지지가 되고 싶다는 바람들을 가지고 있었다. 다만, 은정아버지의 심층 면담에서처럼 놀이하는 아버지 상에 대한 대중매체의 과도한 분위기 조성, 아내의 요구는 아버지들로 하여금 젠더로서의 남성성마저 희석시키면서 무조건 수용, 적 응해야만 하는 정서적 부담감을 갖게 했다. "마초적 근성도 사 라지고”라는 은정아버지의 이야기에서 알 수 있듯이 어머니 와 유사한 양육 실행을 통해 남성보다 여성의 특질을 자연스 럽게 체화하였고, 남성다움에 대한 신념에 의문을 가지게 되 었다. 또한 “무조건 따라야 한다.”는 체념 섞인 목소리에서 느

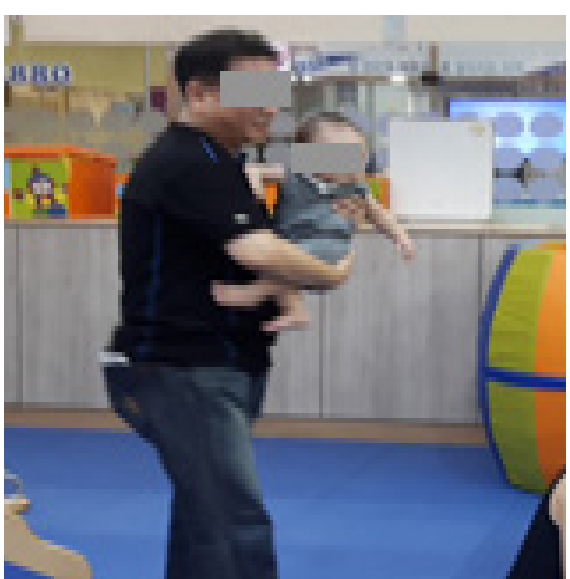

Figure 12. Chang-dae's father cannot control Chang-dae's demands to move repeatedly. Participation observation Chang-dae's father, September 13, 2016.

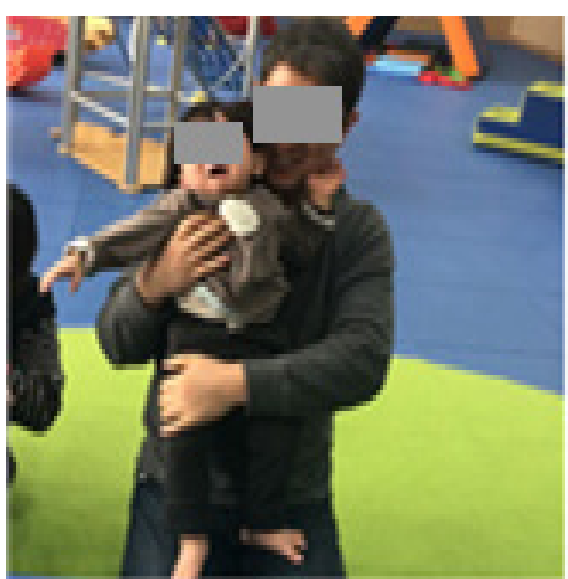

Figure 13. When Sang-jin's father is annoyed that Sang-jin is not playing his way, he is embarrassed and cannot figure out how to handle it. Participation observation Sangjin's father, October 29, 2016.

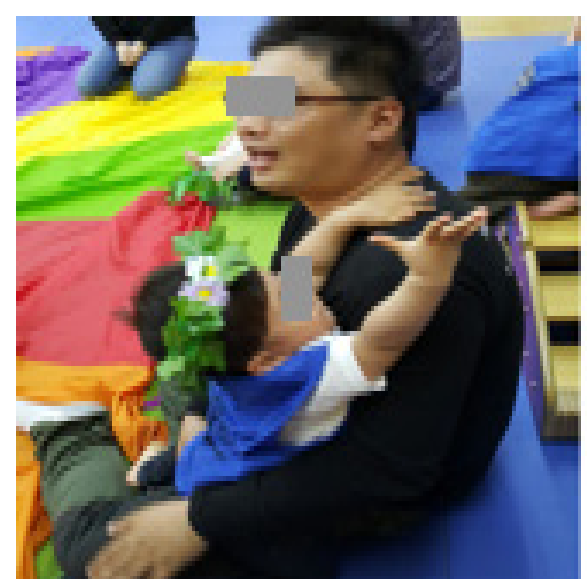

Figure 14. Eun-jeong's father cannot control Eun-jeong being stubborn. Participation observation Eun-jeong's father, September 25, 2016. 
낄 수 있듯이 '할 수밖에 없는 상황', '안하면 안 되는 상황' 때 문에 적극적으로 놀이하는 아버지가 되기도 하였다.

\section{영아기 자녀와의 신체동작 놀이가 아버지 되기 경험에 주는 의미}

남성들은 일상생활에서 자녀와의 상호작용을 통해 아버지로 서의 역할을 수행하고, 부성에 관한 사회적 맥락 속에서 자신 을 연결 지으며 천천히 아버지가 되어간다(Palkovitz, 2002). 하 지만 출산하지 않는 몸의 '제 3자적 위치성'을 지닌 아버지들 은 무엇보다 자녀와 출생 자체에서 어머니처럼 정서적 관계가 이뤄질 수 없기에 자녀 출생 후 함께한 시간의 축적을 통해 관 계 형성이 가능하며, 이는 점진적으로 이뤄진다 $(\mathrm{Na}, 2014 \mathrm{a})$. 그 런데 여기서 아버지들이 일상에서 영아기 자녀와 상호작용을 통해 친밀감과 애정을 표현하는 대표적 방식은 놀이다(Parke, 1996). 놀이 상호작용은 아버지와 영아기 자녀 간의 정서적 연 결 고리인 유대감 형성의 중요한 수단(Lamb, 2010), 즉 애착 발 달의 가장 근본적인 기제로써 아버지가 자녀를 돌보는 과정 에서 아버지로서의 정체감을 발달시키게 된다(Hwang \& Baik, 2005). 그렇다면 이러한 영아기 자녀와의 신체동작 놀이는 한 남성이 아버지로 전환하는 아버지 되기 경험에 어떠한 의미를 갖는가? 본 연구자의 분석에 의하면 '몸 상호작용으로 관계 맺 기', ‘나에서 아버지 되기', ‘성숙한 아버지로 거듭나기', ‘몸 놀이 로 가족 행복 더하기'라는 의미를 갖는 것으로 해석되었다.

\section{몸 상호작용으로 관계 맺기}

몸 움직임으로 이뤄지는 신체동작은 대상과의 관계를 통해 서 이뤄진다. 영아들은 아직 기기, 걷기, 단순 소도구 조작하기 와 같은 초보 동작을 하지만 자신의 신체를 다양하게 움직이 면서 신체에 대한 자의식뿐만 아니라 타인과 원만한 관계를 형성하게 된다(Oh et al., 2000). 또한 몸을 매개로 자신만의 세 계를 구성하고, 능동적 몸 감각에 기초한 지각과정을 거쳐 외 적 대상과 자신을 연결시켜 관계를 맺게 된다(Merleau-Ponty, 1976/2002).

연구 참여자 아버지들은 영아기 자녀와 신체동작 놀이를 하며 '말하는 몸', 즉 비언어적 동작을 통해 상호 간의 보조, 지 지, 반응을 보이며 교감을 형성하고, 피부가 맞닿아 긴밀한 몸 접촉이 생기는 영아기 자녀와의 동작 하나하나에서 친밀감을 형성하였다. 특히, 자녀의 몸동작에 합(合)을 맞출 때 느껴지 는 혈연인식은 무엇보다 뜨거운 부성애의 의미를 생각해 볼
수 있는 동기가 되었다. 결국 아버지와의 신체동작 놀이가 몸 에 찍힌 지문처럼 신체화된 경험으로 축적되어, 자녀가 성장 한 후에도 잊혀지지 않는 정서적 유산으로 남길 바라고 있었 다. 따라서 신체동작 놀이는 아버지와 영아기 자녀 간에 발생 되는 움직임, 즉 몸을 매개로 한 동작이 연결해 주는 관계 속에 서 영아기 자녀와 점차적인 친밀감을 형성시켜 주고, 신체 놀 이 상호작용 속에서 보여주는 자녀의 신체동작과 반응을 통해 즐거움, 기쁨, 애정, 교감을 느끼도록 하였다. 결국 아버지와 영아기 자녀가 정서적으로 연결되는 유대감 형성의 중요한 과 정이 되었다.

창대는 아직 아기라서 말을 잘 못하고, 손가락으로 가리키 거나 웅얼거리면서 말을 하긴 하는데 $\cdots$ 그렇다 보니 $\cdots$ (중 략) 서로를 항상 쳐다보고 몸의 움직임을 맞추고, 그러면서 창대와 저, 이렇게 둘만이 집중적으로 교감할 수 있는 시간 을 갖는 거죠.

(심층 면담, 창대아버지, 2016. 10.27.)

아이와 친해지는 것도 단계가 있는 것 같아요. 인스턴트식 사랑이 아닌 것처럼 $\cdots$ 무턱대고 아이를 안아주게 되면 아이 가 싫어하죠. 그러면 애는 오히려 부작용 나고 불편해해요. (중략) 눈을 마주치고 서로 감정이 통했을 때, 가슴이 통했 을 때 뭔가 느낌이 오는 거죠. 그때 몸으로 '애정표현'을 하 고 $\cdots$ 그때가 바로 신체놀이를 하면서 라는 거죠. 아이가 저 와 즐거움을 함께하면서 가슴이 통하고 눈도 맞추고 살도 닿고 하면서 $\cdots$ 아빠에게 의지하면서 $\cdots$ 아빠를 편하다고 생 각하는 거죠. 그러면서 친밀도는 굉장히 높아지는 거고 $\cdots$

(심층 면담, 새봄아버지, 2016. 10. 28.)

아영이와 살이 닿고, 아영이에게 제 살갖의 느낌과 체온이 전해지고, 반대로 아영이의 살이 느껴지고, 체중이 느껴지 고 $\cdots$ 그러는 데, 뮈 $\cdots$ 몸으로 전해지는 그런 느낌이 좋죠. 거기다 노는 것까지 저와 비슷한 점을 발견하게 되면 "내 핏줄', ‘내 생명'이라는 뭔가 신비로운 느낌이 있어요.

(심층 면담, 아영아버지, 2016. 10. 13.)

처음 산후조리원에서 아기를 안았을 때는 그냥 나와는 크 게 상관없는 하나의 생명체다 뭐 그런 느낌이었어요. 산후 조리원 이모들이 '은정아빠’라고 부르는 데도 얼마나 어색 했는지 $\cdots$ 근데 지금은 아이를 자주 안아서 놀아주다보니 $\cdots$ 아이가 움직일 때마다 뭔가 내 몸과 맞아가면서 뼈들이 움 


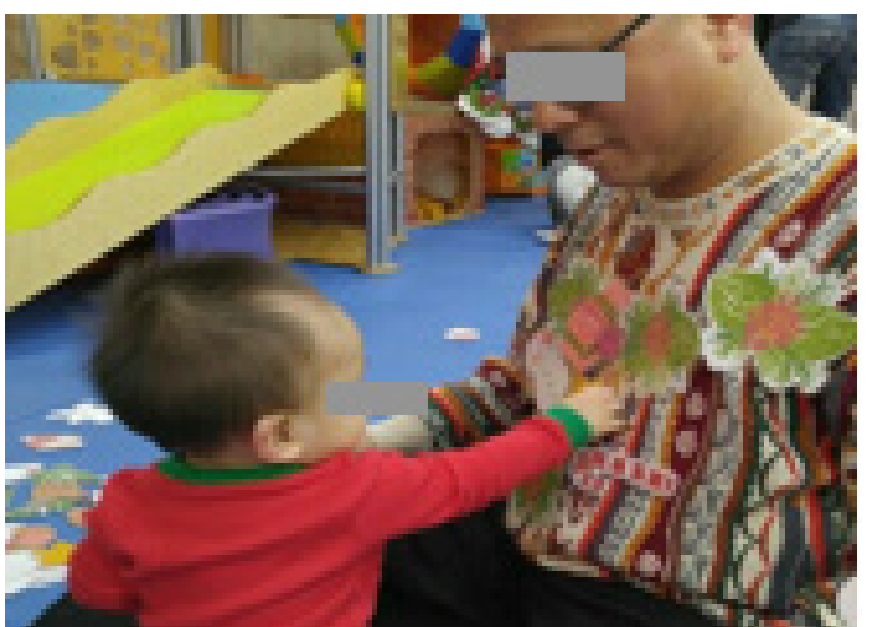

Figure 15. Chang-dae's father responds actively, when Changdae reaches out a toy to his father's clothes. Participation observation Chang-dae's father, October 20, 2016.

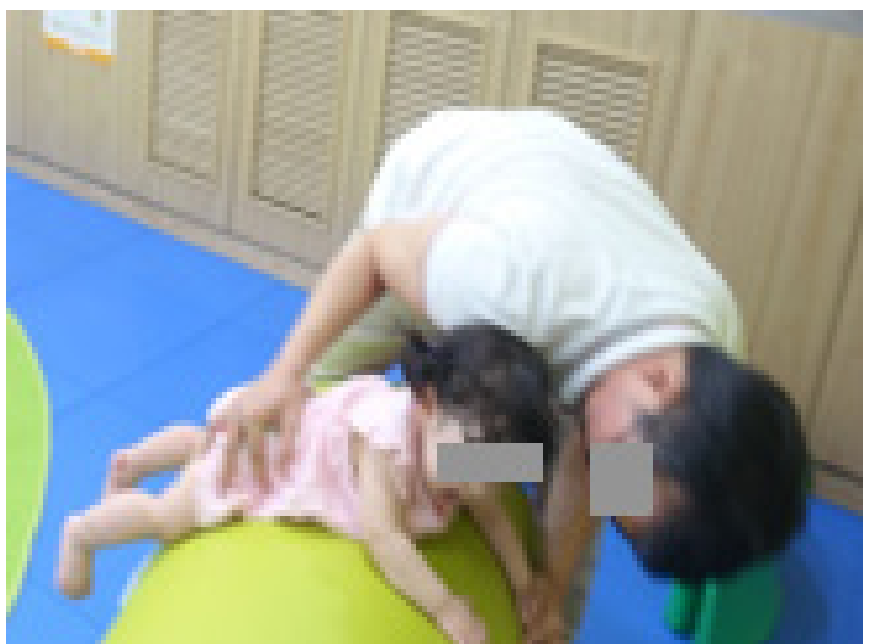

Figure 17. Eun-jeong's father plays with Eun-jeong with eye contact. Participation observation Eun-jeong's father, October 12, 2016.

직이는 게 다 느껴지면서 뮌가 살려달라는 것 같기도 하고 내가 지켜야할 것 같기도 하고 $\cdots$ 그러면서 움직임 하나하 나가 나를 닮은 것 같기도 하면서 '내 자식' 같다는 생각이 들고 그래요.

(심층 면담, 은정아버지, 2016. 10. 12.)

위의 사례들 가운데 창대아버지의 심층 면담과 Figure 15 참 여 관찰에서 영아기 자녀는 아버지의 몸에 장난감을 붙이며, 아버지 몸을 탐색하고, 그 즐거움을 비언어적 의사소통 수단 인 손짓, 몸의 움직임과 같은 동작을 통해 언어보다 더 섬세히

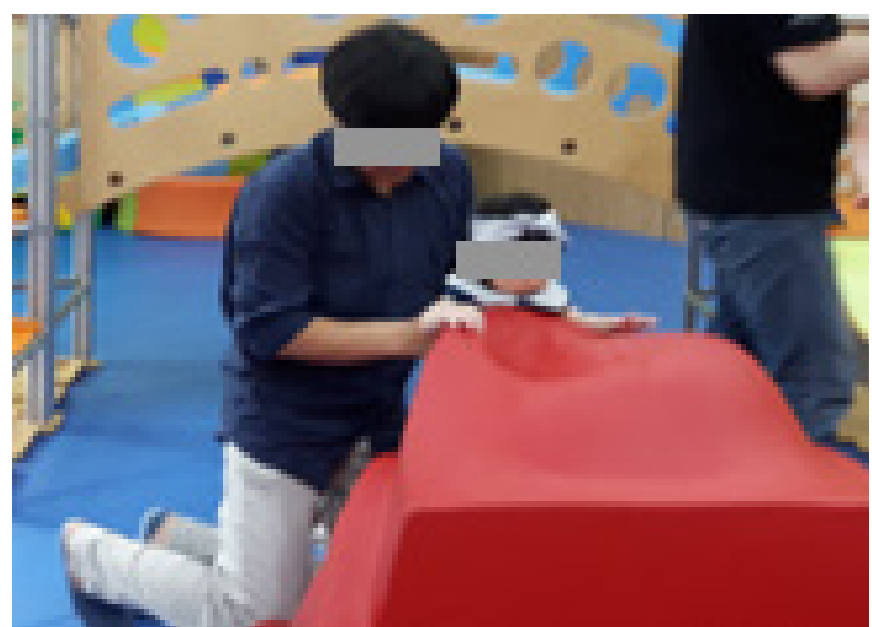

Figure 16. A-yeong's father assists in the activity carefully, grasping A-yeong, who tries to climb the equipment. Participation observation A-yeong's father, October 13, 2016.

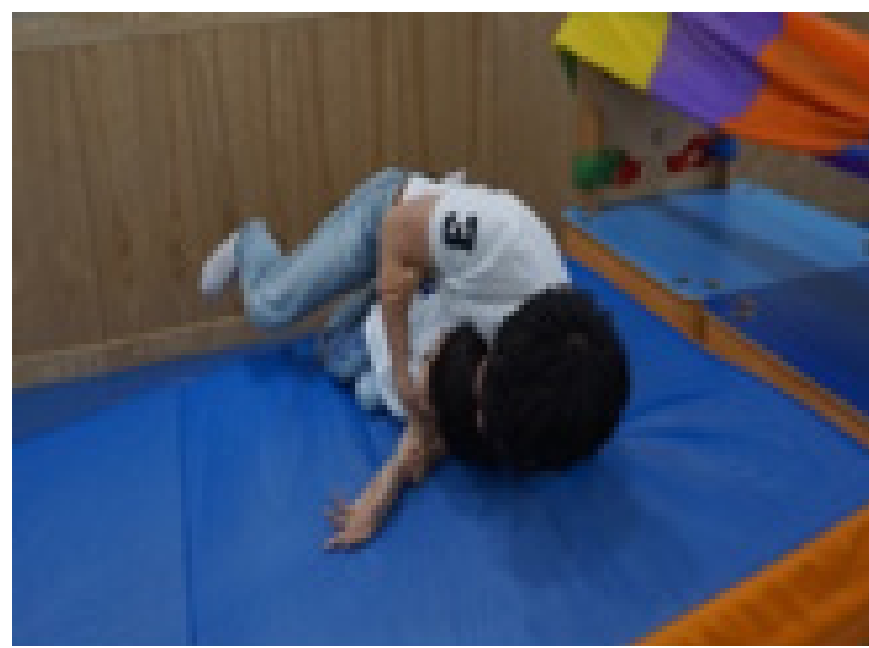

Figure 18. Sae-bom's father rolls all over on the mat with Saebom. Participation observation Sae-bom's father, October 28, 2016.

표현하였다. 창대아버지는 그 마음과 표현을 읽기 위해 자녀 에게 집중하여 반응을 보였고, 자녀는 그에 대한 아버지의 동 작 반응에 아빠 몸 두드리기와 같은 또 다른 동작 반응으로 감 정을 전달하였다. 이처럼 지속적 애착관계를 형성하는 어머 니-자녀 관계와 달리 평상 시 몸 접촉이 부족한 아버지들에게 신체동작 놀이는 새봄아버지의 심층 면담에서처럼 무조건 기 다리거나 서둘러도 안 되는 애정표현으로써 친밀감을 형성하 고, 심리적 거리감을 줄여주는 효과적 방법이자, 신체적 - 정서 적 교감을 나누는 공감과 소통의 장이 되었다. 또한 Figure 16, 17,18 참여 관찰에서 볼 수 있듯이 아버지들과 자녀 간의 밀 


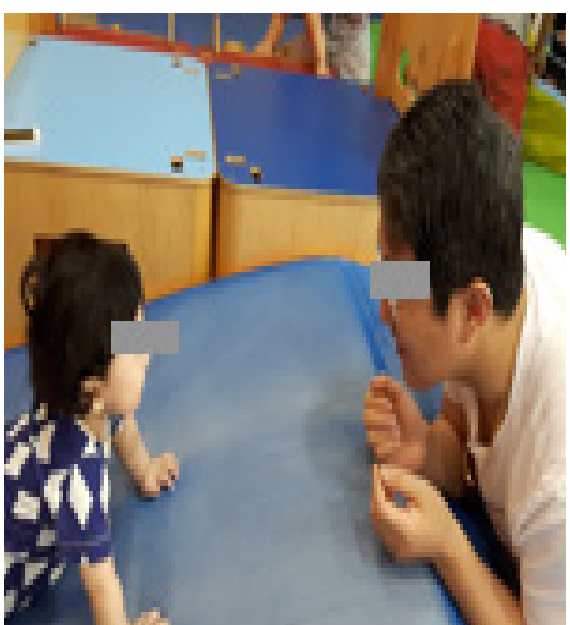

Figure 19. Sang-jin's father meets Sangjin who comes to the top of the inclined mat and says "abbabba" with a smile. Participation observation Sang-jin's father, September 24, 2016.

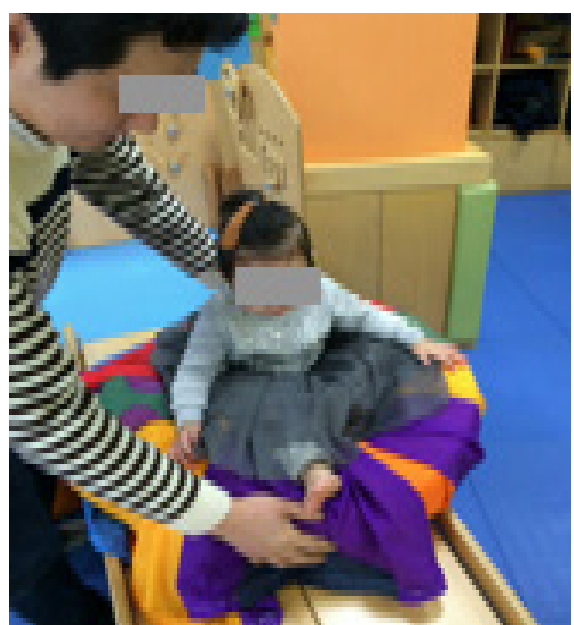

Figure 20. Sang-mi's father supports Sangmi on the slide, as Sang-mi tries for the first time with a comfortable face. Participation observation Sang-mi's father, November 19, 2016.

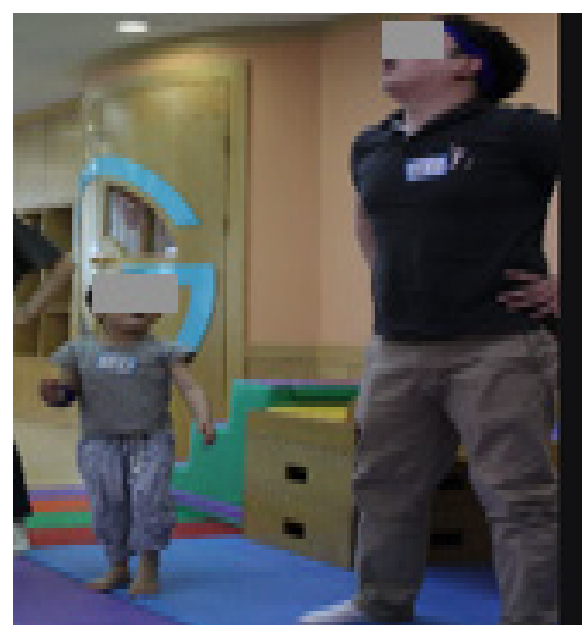

Figure 21. Sae-bom looks with envy at his father's big movements. Participation observation Sae-bom's father, October 28, 2016.
착된 몸 접촉 과정에서 자녀의 몸 움직임이 아버지들의 피부 로 생생하게 전달되고, 자신의 생명으로부터 비롯되었다는 동 질성을 발견하게 되었다. 결국, 아영아버지와 은정아버지의 심층 면담에서처럼 어머니가 느끼는 자녀의 태동과 차원이 다 른 생명의 신비로움과 경외감, 그것을 넘어선 내 핏줄, 내 생 명, 내 자식이라는 혈연관계를 인식할 수 있었다.

\section{나에서 아버지 되기}

어머니들이 임신을 통해 모성의 역할을 인식하는 것과 다르 게, 아버지들은 임신기라는 생물학적 적응기 없이 부모 전이 기에 진입하기 때문에 아버지로서의 새로운 역할을 쉽게 내면 화하지 못한다(Seo, 1999). 뿐만 아니라 부성은 사회·문화적, 경제적 요인에 따라 사회적으로 구성되며, 부성 정체성 또한 자녀를 경제적으로 부양하고, 신체적으로 보호하며, 아버지로 서의 권위, 규율 등 사회·문화적으로 요구되는 역할들을 복합 적으로 실천하는 가운데 형성된다 $(\mathrm{Na}, 2014 \mathrm{~b})$.

연구 참여자 아버지들은 영아기 자녀와의 신체동작 놀이를 통해 타인에서 어머니와 다른 새로운 양육자로서 자녀에게 인 식되면서, 아버지로서의 존재감을 확인하고, 자녀에게 신뢰감 을 형성하였다. 즉, 동작의 주체와 대상이 함께 동작을 하기 위 해서는 상호관계 속에서 이루어지는데 계속적인 신체동작 상 호작용이 축적될수록 연구 참여자 아버지들은 영아기 자녀의 놀이를 단순히 보조하거나 지지하는 존재를 넘어 자녀에게 없
어서는 안 되는 필수 존재로서 각인되어감을 인식하게 되었 다. 또한 거칠게 따라잡기, 뒹굴기, 오르기 등과 같은 거친 신 체동작이 있는 경우에는 아버지의 동작에 대한 자녀의 무조건 적인 수용 반응에서 아버지로서의 권위를 발견하기도 하였다. 특히, 영아기 자녀가 자신의 힘 있는 큰 신체동작 모습을 선망 과 동경의 눈빛으로 바라볼 때는 더욱 그러했다. 신체동작 놀 이 과정 또는 후에 느끼게 되는 연구 참여자 아버지들의 충만 한 기쁨, 성취감과 만족감은 아버지 스스로 자신을 '충분히 좋 은 아버지'라고 표현할 수 있을 만큼 자신감과 아버지 효능감 으로까지 확대되었다.

상미가 겁이 많다는 애기를 들었는데, 저와 신체 놀이 할 때 제가 잘 잡아주겠다고 하니깐 처음으로 시도했어요. 그리 고 다 하고, 제품에 안기는데 $\cdots$ 뭔가 짠한 기분 $\cdots$ 내 딸 상 미가 아빠를 의지하는구나. 나를 믿는구나. 내가 상미의 아 빠 맞구나 내가 상미의 안식처라는 생각까지 들었어요.

(심층 면담, 상미아버지, 2016.9. 17.)

새봄이와 아주 거칠게 놀거나 몸을 움직이면, 반응에 뭐라 고 해야 하나 복종은 아니고 왠지 '와! 우리 아빠 대단 하시 네.' 하는 선망? 존경의 눈빛이 느껴져요. 박력 있게 군대에 서 배운 태권도 동작 하나만 보여줘도 $\cdots$ 두 팔을 크게 벌려 약간의 공포감을 주며 따라가거나 하면, 자지러지게 소리 지르고 그러죠. 엄마는 그냥 놀이 안에서 따뜻함을 준다면, 
아빠는 자녀를 지지하면서 '권력'이라든가 ‘힘’을 느낄 수 있도록 하는 것 같아요.

(심층 면담, 새봄아버지, 2016. 10. 28.)

놀고 나면 저에 대한 아이의 반응이 확실히 달라요 애들이 뭐 사준다고 그러한 반응을 보이진 안잖아요. 잠깐뿐이고. 근데 확실히 달라요. 몸으로 노는 건... 거기다 와이프까지 흐뭇해 하면 ‘아 내가 잘하고 있구나...' 그런 느낌이 들잖아요. 동기 부여가 더 되죠. '나, 정말 좋은 아빠네.' 와이프도 저의 그런 모습을 보고 좋아하고 칭찬하네. 그러면서 더하게 되죠.

(심층 면담, 아영아버지, 2016. 10. 29.)

상진이가 요즘 많이 몸으로 놀아준 이후로 저만 보면 “아빠 빠빠.”라고 말을 하기 시작했어요. 처음 한말이 엄마가 아 니라 “아빠”. 열심히 놀아준 보람이 있구나... 정말 만족해 요. (중략) 이정도면 아빠로서 'Not bad, 그래도 좋은 아빠 야.'라는 생각도 들고요.

(심층 면담, 상진아버지, 2016. 9. 24.)

위의 상진 아버지의 심층 면담과 Figure 19 참여 관찰, 상미아 버지의 심층 면담과 Figure 20 참여 관찰에서 볼 수 있듯이 연 구 참여자 아버지들은 신체동작을 매개로 한 놀이 상호작용 에서 어머니의 신체적 돌봄과 다른 방법으로 영아기 자녀에 게 지지와 믿음, 새로움에 대한 도전감을 심어주는 행동과 반 응들을 보여주었다. 이는 영아기 자녀들이 아버지의 놀이 활 동에서 안전감을 형성하게 하는 촉매제가 되었고, 이러한 안 전감이 기반이 되어 영아기 자녀들은 점차 아버지를 신뢰의 대상으로서 인식하게 되었다. 연구 참여자 아버지들은 자녀 가 시도조차 어려웠던 신체동작 놀이를 하게 되고, 활동 수 행 후 자신의 품에 안기는 모습을 보면서 상미아버지의 이야 기처럼 “내가 누군가의 아빠가 맞구나.”라는 생각을 갖게 되 었다. 이를 통해 자녀와의 신체동작 놀이 과정에서 아버지들 은 한 사람의 남성이 아닌, 누군가의 아버지, 보호자로서 정체 성을 형성해 간다는 것을 알 수 있다. 또한 새봄아버지의 심 층 면담과 Figure 21 참여 관찰에서 볼 수 있듯이 영아기 자녀 들은 아버지들의 절도 있는 큰 동작을 선망의 눈으로 바라보 고, 아버지의 동작 모습 그대로 모방하려고 하였다. 이는 거친 신체동작 놀이에서 새봄아버지가 표현한 권력과 힘이라는 단 어처럼, 연구 참여자 아버지들은 어머니가 줄 수 없는 남성성 (masculinity)이 지닌 강력한 힘을 바탕으로 영아기 자녀의 넘 치는 신체 에너지를 조절하고 때로는 통제하며, 아버지에 대
한 존경과 의존성을 갖게 함을 알 수 있다. 결국, 연구 참여자 아버지들은 권위 있는 존재로서 인식되면서 스스로 아버지 역 할을 인식하고 내면화하는 과정을 경험하게 되었다.

\section{성숙한 아버지로 거듭나기}

아버지들은 임신으로 태내에서부터 자녀를 인식하고 영아기 애착을 통해 정서적 유대감을 형성하는 어머니와 달리 구체적 행위들의 연속적 실천에 의해 아버지로 인식된다( $\mathrm{Na}, 2014 \mathrm{~b})$. 또한 아버지 되기 과정에서의 구체적 행위의 연속적 수행은 아버지들에게 즐거운 경험이자, 개인적인 성숙을 이룰 수 있 는 경험이 된다(S.-Y. Kim, 2012).

연구 참여자 아버지들은 영아기 자녀에 대한 양육 지식, 기 술, 이해 부족으로 양육의 수동적 존재로서 소외감과 위축감 을 느끼기도 하였다. 하지만 신체동작 놀이 과정에서 양육 역 량을 키워가고, 가족 내에서의 모호했던 역할을 서서히 찾아 가며 자녀의 성장과정에 도움을 주는 능동적 존재로 변화하게 되었다. 무엇보다 신체동작 놀이를 통해 아버지로서의 역할을 연속적으로 실천하고 수행하는 과정에서 그동안 어머니의 역 할로만 간주되던 자녀의 발달을 점검하고 앞으로의 양육 방향 등에 대해 관심을 갖게 되었다. 뿐만 아니라 초보 놀이 학습자 로서 단순히 신체 놀이를 익혀가는 것이 아니라, 신체화된 놀 이 기억들을 되살려 놀이성을 회복하며 눈높이를 맞춘 놀이 파트너가 될 수 있었다. 이러한 모든 과정들은 연구 참여자 아 버지들이 결국 경제적 역할뿐만 아니라 자녀 양육에도 적극 적으로 참여하는 아버지의 역할을 보다 구체화하고, 성실성과 삶의 목적성을 뚜렷하게 함으로써 성숙한 아버지로 거듭날 수 있는, 무엇보다 성장할 수 있는 기반이 되었다.

은정이가 지금보다 더 어릴 적에는 안고 있을 때 뭔가 불안 정하고 어색한 느낌이 참 많았어요. 제가 너무 부족한 아빠 라는 게 $\cdots$ 아내나 장모님은 그렇지 않았는데, 그럴 때 왠지 질투심 같은 것이 느껴지기도 하고, 은정이가 아내와 붙어 있는 것을 보면 정말 소외된다는 느낌이 들었고요. 그런데 그런 생각들이 그냥 무작정 들었던 것 같아요. 이제는 몸으 로 많이 놀아주니깐 확실히 꼭 저랑만 놀려고 하고, 여기도 저랑만 가려고 하고, 요즘에는 오히려 아내가 은정이와 저의 사이를 질투하는 느낌이 들어요. 뭐든 자신감이라는 게 그냥 생길 수 없다는 것을 알게 되었죠. 그러면서 아빠로서, 남편 으로서 제가 가지고 있던 생각이 많이 바뀐 건 확실하고요.

(심층 면담, 은정아버지, 2016. 10. 29.) 


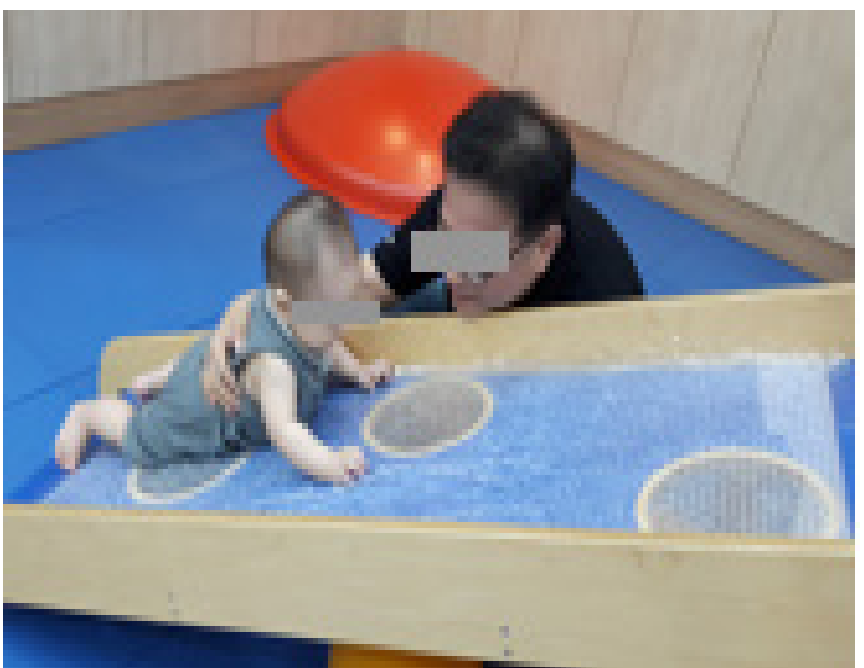

Figure 22. When Chang-dae stops and explores an air cap while climbing a slide, Chang-dae's father observes carefully. Participation observation Chang-dae's father, September 13, 2016.

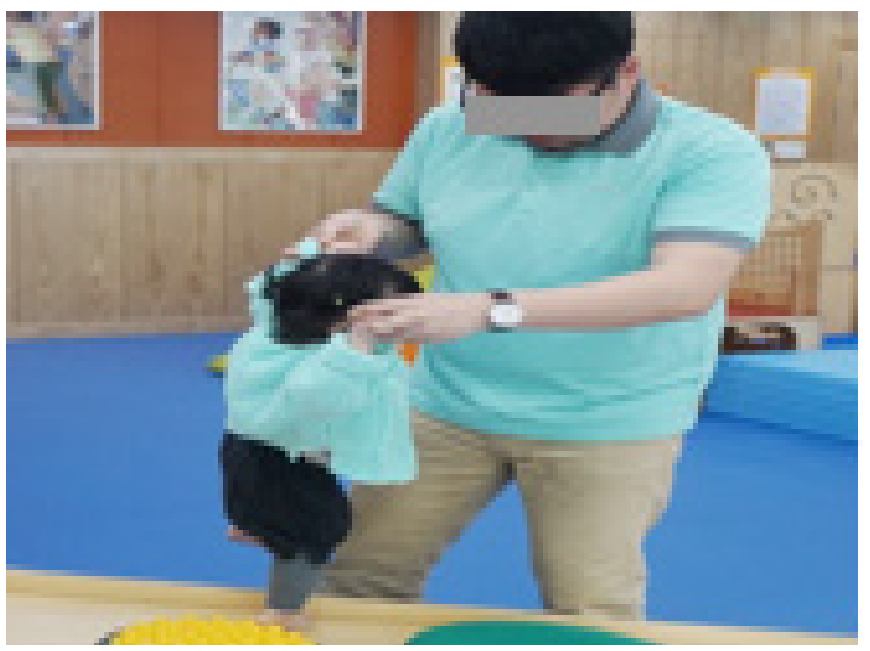

Figure 24. Eun-jeong's father observes Eun-jeong trying to walk. Participation observation Eun-jeong's father, October 5, 2016.

예전에는 ‘중간대리인’ 같았죠. 새봄이와 제가 서로 익숙하 지 않고, 직접 소통할 시간, 기회자체가 부족하니깐... 아웃 사이더? 때론 '집안의 왕따' 당하는 느낌도 들고... (중략) 하지만 이제는 더 이상 저도 그냥 ‘아웃사이더'가 아니라는 거죠. 그렇다 보니 이젠 아빠로서 무게감이 확실히 달라졌 어요. 성장과정에 도움을 줄 수 있는, 주고 있는 존재, '진짜 아버지'가 되고 있구나 라는 생각이 들죠. 아빠로서의 의무 감 같은 것들이 더 진해지고 강해지죠. 아빠 되기는 쉽지만 아빠답기는 어렵잖아요 $\cdots$

(심층 면담, 새봄아버지, 2016. 11. 18.)

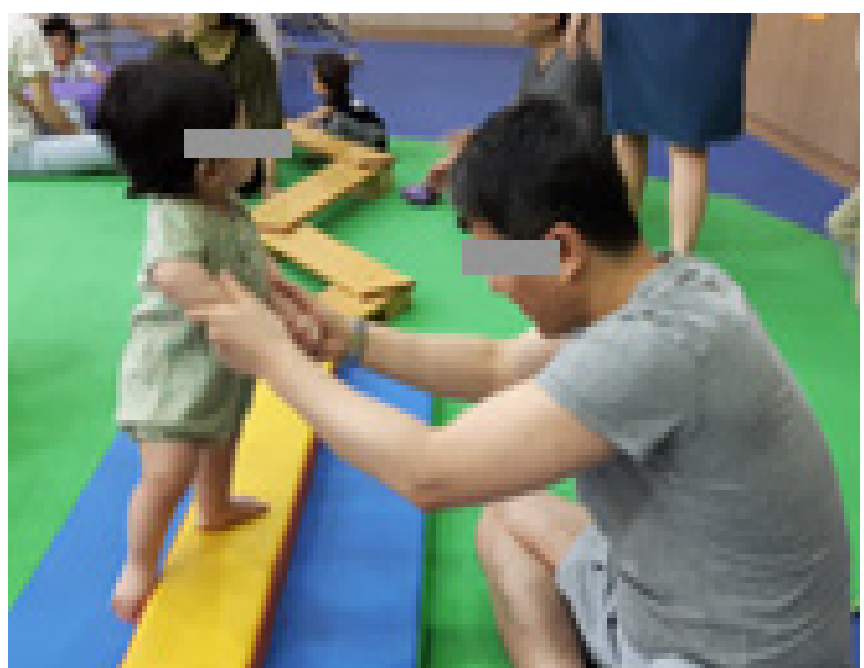

Figure 23. When Sang-jin is able to stand in the balance, Sangjin's father is happy to observe. Participation observation Sang-jin's father, September 10, 2016.

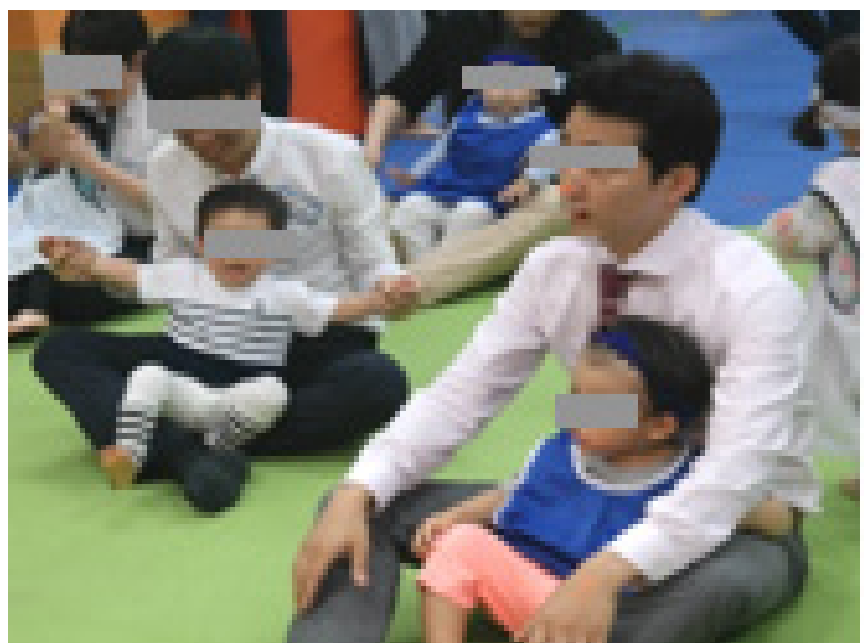

Figure 25. A-yeong's father listens to the teacher's explanation. Participation observation A-yeong's father, November 18, 2016.

그동안에는 아이에 대해 전혀 모르니깐 '뜬구름 잡는' 상태 였는데, 이제는 상진이를 자꾸 관찰하는 버릇이 생겼어요. 상진이 주변도 유심히 보게 되고, 다른 아이들과 발달상태 같은 것도 비교하게 되고, 상진이의 소심한 면도 알게 되고, 무엇보다 어떤 부분에서 적극적으로 활동하는 것도 직접 보게 되니깐 이런 것을 좀 더 해 줘야겠구나... 계획까지도 세우게 되고 $\cdots$ 저의 가장 큰 변화, 잘 하게 된 것은 상진이 에 대한 연구를 하게 된 거죠.

(심층 면담, 상진아버지, 2016. 10. 27.) 
사실 처음에는 다른 아빠들 노는 것 지켜만 보다가... 근데 이제는 내가 제일 잘 놀아주는 아빠가 되고 싶은 경쟁심도 생기고. 힘센 아빠가 아이를 높이 들면 저는 아영이를 더 높 게 들어서 놀아주게 되고 $\cdots$ 아영이가 더 크게 웃을 수 있 게. 그러면서 저도 놀이에 몰입하면서 더 열심히 놀게 되 기도 하고, 사실 젊었을 때는 공공장소에서 아이들 있으면 피하기도 하고 그랬던 저였는데 $\cdots$ 무엇보다 아빠로서 제가 참 많이 변해가는 것 같아요. 아영이에게 눈높이를 점점 더 맞추게 된다고나 할까...

(심층 면담, 아영아버지, 2016. 11. 17.)

위의 사례들 가운데 은정아버지와 새봄아버지의 심층 면담에 서 알 수 있듯이 영아기 자녀와 신체동작 놀이 경험을 충분히 쌓기 전, 연구 참여자 아버지들은 그 어느 시기보다 조심히 영 아기 자녀를 다루는 과정에서 두려움을 느끼고, 그런 상황에 서 아내가 능숙하게 자녀를 다룰 경우 질투심을 느끼기도 하 였다. 하지만 신체동작 놀이 과정에서 자녀가 아버지만 찾는 것처럼 긍정적 반응 등을 경험하며 부족한 아빠, 집안의 왕따, 중간대리인, 아웃사이더로 자신을 표현하던 연구 참여자 아 버지들은 가족 내에서의 모호했던 역할을 서서히 찾아 가면 서 소외감과 위축감에서 탈피할 수 있었다. 또한 상진아버지 의 심층 면담에서 신체동작 놀이를 처음 시작할 때 '뜬구름을 잡는 것'과 같다는 표현을 할 정도로 연구 참여자 아버지들은 영아기 자녀에 대한 양육역량이 부족한 상태로 시작하였지만, Figure 22 창대아버지, Figure 23 상진아버지, Figure 24 은정아 버지의 참여 관찰에서 볼 수 있듯이 영아기 자녀가 놀이과정 에서 보여주는 표정, 몸짓, 신체동작 등 소소한 행동 하나하나 에도 관심을 갖고 유심히 관찰하는 태도를 갖게 되었다. 즉 아 내와 공동 양육자로서, 자녀의 성장 동반자로서 '관찰자의 눈' 으로 자녀의 발달 상태를 파악하고 특징적인 부분과 부족한 부분들을 찾아 양육전략까지 수립하는 '역량 있는 양육자'로 성장하는 중요한 계기를 마련하였다. 더불어 아영아버지의 심 층 면담과 Figure 25 의 참여 관찰에서처럼 연구 참여자 아버지 들은 외부의 시선에서 자유로워지고, 자녀와의 놀이 역할 경 험이 축적됨에 따라 아내나 교육 기관으로부터 단순히 놀이를 배우고자 하는 놀이 학습자, 보조자, 지원자의 태도에서 벗어 나 자녀와 하나가 되어 적극적으로 놀이에 몰입하고, 영아기 자녀와 눈높이를 맞춰가며 '놀이 파트너'의 역할을 수행하게 되었다.

$$
\text { 몸 놀이로 가족 행복 더하기 }
$$

아버지와 자녀 간의 관계는 부모와 자녀 사이의 관계 확인에 서만 그치는 것이 아니라 가족이라는 테두리 안에서 모든 상 호관계를 봐야 하는데, 그 이유는 가족 공동체는 단독으로 존 재하는 것이 아니라 유기체로서 가족 구성원과 서로 연결되어 있기 때문이다(Jang \& Yun, 2014).

연구 참여자 아버지들은 몸을 매개로 한 신체동작 놀이에 서 단순히 살과 살이 맞닿은 신체 접촉이 아닌 교감과 소통이 있는 정서적 공감 과정을 거쳐 실제로 유기체적 가족 관계를 인식하게 되었다. 이로 인해 영아기 자녀와 단순히 혈연관계 로 맺어진 놀이 파트너가 아닌 한 팀과 같은 가족 구성원으로 서 연대감을 형성할 수 있었다. 또 아내와는 공동 양육자로서 자녀 양육에 대해 서로의 지식과 관점을 수용하고 배워나가 는 파트너십을 통해 부부 연대감을 형성하며 친밀도를 높일 수 있었다. 결국, 신체동작 놀이라는 양육 실제에서 몸 놀이 가 맺어주는 상호작용을 통해 아버지, 어머니, 자녀라는 가족 구성원 간의 연대의식을 견고히 하여 가족애를 키울 수 있었 다. 또한 웃음이 넘치고, ‘몸과 마음이 건강한 가족 실현’이라 는 가족의 지향점을 찾을 수 있었다. 즉 연구 참여자 아버지들 은 신체동작 놀이라는 양육경험을 통한 아버지 되기 과정에 서 가족 공동체가 가지는 진정한 의미와 행복의 가치를 발견 할 수 있었다.

몸이 맺어주는 신체 놀이라는 연결체를 통해서 (중략) 마치 $\mathrm{DNA}$ 게놈의 위치를 서로 찾아가듯 $\cdots$ 그러다가 그런 경험 들과 시간이 쌓이면서 아버지와 아들의 관계를 찾아가게 되는 거죠. (중략) 저와 창대는 지금의 이런 관계가 오랫동 안 이어지는 관계로 발전되길 소망하죠. 신체적 혈연을 넘 어서 '너와 나는 한 팀, 한 가족, 패밀리'가 되어야죠. 패밀 리의 본래 어원인 라틴어 '파밀리아' 말고 '파더 앤 마더'라 고 해석하는 경우도 있는데 $\cdots$ 그래서 서로 의지하고, 사랑 을 나누고, 비전을 찾아가는 것, 가치를 찾아가는 것. 그래 서 가족의 가치가 그 안에 존재하는 거죠.

(심층 면담, 창대아버지, 2016. 11.22.)

와이프와 정말 더 가까워지는 것 같아요. 이제는 와이프만 육아를 하는 게 아닌 거죠. 아내의 양육 파트너가 될 수 있 는 거고. 양육에 서로 다른 부분들을 짝을 맞추듯 하나로 만 들어가는 것이 상당히 필요할 것 같아요. 그런데 그렇게 하 려면 부부관계를 친밀하게 만드는 '맞추고 조여 주는 나사' 


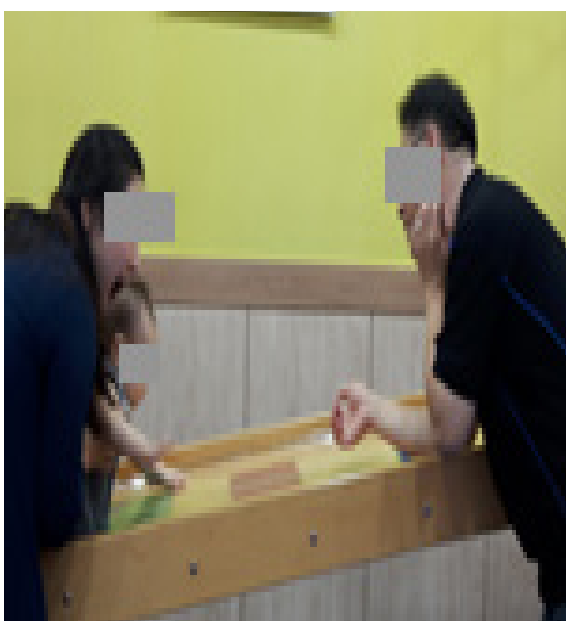

Figure 26. Chang-dae's parents look on happily as Chang-dae goes up the slide. Participation observation Chang-dae's father, October 26, 2016.

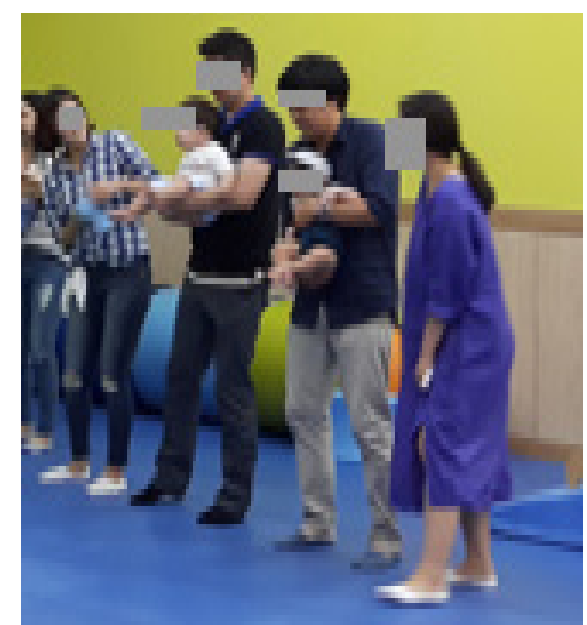

Figure 27. Eun-jeong's father and other fathers exercise with their children, and the mothers smile as they look. Participation observation Eun-jeong's father, October 27, 2016.

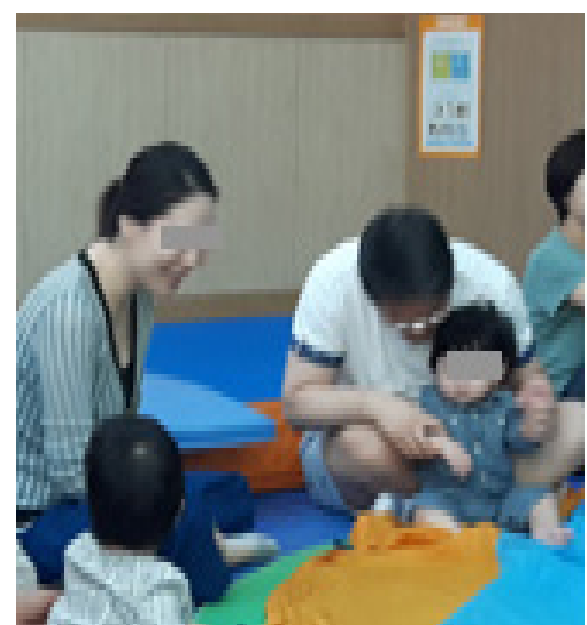

Figure 28. Sang-jin's father takes Sang-jin's hand and dance to the rhythm of Sang-jin's movements, and Sang-jin's mother smiles. Participation observation Sang-jin's father, October 3, 2016.
같은 뭔가가 필요한데 그게 '신체 놀이'라는 생각이 들어요. (심층 면담, 아영아버지, 2016. 11. 17.)

저랑 놀고 난 다음에는 상진이가 엄청 웃어요. 와이프도 좋 아하고, 저도 기분이 정말 좋죠. 집안에 아이의 웃음소리가 들리면 좋잖아요. 그러면서 직장에서 힘들고 스트레스 받 은 것도 풀리고 $\cdots$ 마치 피로회복제처럼 $\cdots$ 셋이 함께 웃을 수 있다는 것. 무 $\cdots$ 그게 행복이죠.

(심층 면담, 상진아버지, 2016. 11.9.)

위의 사례들에서 연구 참여자 아버지들은 몸을 매개로한 놀 이 경험 축적을 통해 통해 영아기 자녀와 교감, 소통하면서 상 호적 관계를 형성하고 혈연을 넘어선 새로운 연대감으로 확 장시켰다. 이는 아버지와 자녀와의 관계 형성이 어머니와 자 녀와의 관계에 대한 또 다른 상호보완의 관계를 구축하게 하 고, 심층 면담에서 아영아버지의 이야기처럼 '조임나사'와 같 은 연결체로서 가족 내 응집력을 더욱 높여주는 요인으로 작 용하게 되었다. 또한 Figure 26, 27, 28 참여 관찰에서 연구 참 여자 아버지들과 어머니들이 한곳, 바로 그들의 자녀를 쳐다 보며 행복한 미소를 짓는 모습에서 알 수 있듯이, 연구 참여자 아버지들과 그의 아내인 어머니들은 혈연을 넘어서 신체적, 심리적으로 견고한 연대감을 통해 '한 팀, 한 가족, 패밀리’로 서의 가족의 탄생을 기원하고 있음을 알 수 있다. 결국 이러한 상호관계성을 지닌 신체동작 놀이가 가족 간의 사랑과 신뢰를
증진시키고, 가족 공동의 목표와 가치를 발견할 수 있도록 함 을 살펴볼 수 있다. 창대아버지가 심층 면담에서 언급한 아버 지(father)와 어머니(mother)가 만나서 이뤄지는 가족, '패밀리 (family)'라는 단어는 신체동작 놀이가 아버지 되기 경험에 주 는 의미와 지향점을 아버지들의 눈으로 직접 보게 된 함축적 의미가 되어준다.

\section{Discussion}

본 연구는 아버지들의 대표적 양육형태이자 놀이 강점으로 재 조명 되고 있는 아버지들의 영아기 자녀와의 신체동작 놀이가 어떠한 양상으로 나타나며, 그것이 아버지 되기 경험에 주는 의미는 무엇인지를 살펴보는 데 의의가 있다. 이에 본 연구를 통해 얻게 된 결과를 바탕으로 논의해 보면 다음과 같다.

첫째, 연구 참여자 아버지들은 신체동작 놀이를 처음 시작 하는 과정에서 영아기 자녀의 발달 특성에 대한 이해 및 놀이 상호작용 경험 부족으로 신체동작 놀이의 범위와 방법들을 육 체적 신체에만 집착하여 몸의 움직임과 탐색, 상호작용에 제 한을 두었다. 또한 자신의 아동기 시절 원 가족 부모와 충족되 지 않은 스포츠 놀이 경험을 보상받기 위해 영아기 자녀의 신 체동작 놀이가 스포츠 활동과 연관될 때 더욱 의미를 부여하 여 신체동작 놀이를 실현하고자 하였다. H. Kwon 등(2016)은 영아의 신체 발달은 놀이와 연관되어 나타나며 정교해지는 변 
화가 필요하다고 하였으며, Parke (1996)는 아버지의 놀이는 동적이고 모험적인 놀이 특성들을 발현하는 것이라고 하였다. 따라서 영아의 신체 발달을 고려한 특성들이 잘 발현될 수 있 도록, 그리고 아버지들에게 단지 스포츠 활동이 아니라 친숙 하고 관심 있는 놀이 활동으로서 좀 더 쉽게 자녀 양육에 접근 할 수 있도록(Jung et al., 2010) 하기 위해, 영아가 자녀를 둔 양 육 초보 아버지들을 대상으로 단순 정보 습득이 아닌 양육 실 제의 내용이 포함된(McBride \& McBride, 1993) 부모 교육이 아버지로의 첫 전이기에 절실히 필요하다고 할 수 있다.

둘째, 연구 참여자 아버지들은 격렬한 신체적 놀이와 같은 자극중심의 놀이에 대해 남성의 힘을 강조하며, 남성 고유 영 역이라는 인식 하에 어머니의 정적 놀이와 차별을 두면서 특 별함과 강점을 부여하였다. 영아기 자녀가 보이는 적극적 반 응과 선호를 기준으로 어머니 놀이보다 우위에 두어 서로 비 교하기도 하였고, 자녀와의 정서적 유대와 친밀감 형성을 위 한 도구로 사용하고자 하였다. 이처럼 아버지와의 신체동작 놀이는 영아기 자녀가 욕구충족을 위해 본능적으로 찾는 놀 이 반응으로서 Lamb (2010)의 연구에서처럼 영아기 자녀에게 익숙하고 일상적인 어머니와의 정적 놀이와 달리, 짧지만 보 다 역동적이고 적극적인 놀이 상호작용을 통해, 영아에게 어 머니의 놀이보다 더 인상적인 놀이로 자녀에게 인식되고 있었 다. 이러한 부분은 아버지들 스스로도 지적이고 교훈적인 것 보다 육체적이고 자극적인 놀이를 선호한다는 Clarke-Stewart (1978)의 연구 결과와도 맥을 같이한다. 이에 반해 연구 참여 자 아버지들과 그의 아내들은 어머니들의 놀이를 신체 움직임 이 적고, 돌봄 중심의 양육과정과 태도가 반영된 정적놀이로 한정짓고, 양육에 있어서 놀이의 역할까지 분담하였다. 이를 통해 어머니와 아버지의 놀이 유형 간에 서로 구별되는 특징 들과 놀이참여 역할 구분은 놀이 과정에서 나타나는 놀이 특 성과 참여, 그에 대한 효과적 놀이 촉진, 상호작용 방법의 모색 에서 이뤄졌다고 판단하기 어렵다는 것을 알 수 있다. 또한 초 기 자녀양육에서는 여성의 임신과 출산, 수유로 인한 생물학 적 차이로 인해 어머니의 역할분리가 이뤄졌다면, 그 이후에 는 아버지와 어머니의 체력, 운동능력 등의 차이로 인해 신체 놀이를 아버지의 고유 영역으로 의미를 부여함으로써 부모 간 의 역할분담이 이루어졌음을 생각해볼 수 있다.

셋째, 연구 참여자 아버지들의 신체동작 놀이에서 나타나 는 자녀와의 놀이 상호작용에 대한 태도, 형태, 방법 등은 세대 에 걸쳐 전이 되어 신체동작 놀이를 통한 양육의 현재에 반영 되어 끓임없이 영향을 주는 맥락으로 작용하고 있었다. 연구 참여자 아버지들은 원 가족 아버지의 권위주의적 모습을 기억
하고, 특히 놀이 부재에 따른 부족한 친밀감에 대해 아쉬움을 나타냈다. 그리고 그런 경험과 기억들이 자녀 세대에 전이되 지 않도록 노력하고 있었다. Song 등(2010)은 아버지들이 아동 기 부모와의 관계에서 부정적인 경험을 했지만 이후에 성인이 되어 자신의 부정적 경험을 보상하기 위해 반대되는 방식으로 재구성하여 양육자의 역할을 수행하는 "보상적인 아버지 역 할'을 언급한 반면, Floyd와 Morman (2000)은 영유아기에 자신 의 아버지로부터 긍정적인 양육태도를 경험하게 되면 자신이 아버지가 되어서도 동일한 태도를 취하게 된다고 연구에서 밝 혔다. 실제로 연구 참여자 아버지들 중에도 아동기 즐거웠던 신체동작 놀이 경험을 아버지가 된 현재 시점에서 자녀와의 놀이 상호작용에 자연스럽게 반영하여 자녀와 공유하며, 세대 를 거듭한 즐거운 추억으로 재저장하는 경우도 있었다. 이는 아버지들이 원 가족 아버지의 긍정적 놀이 역할 모델링 가운 데 장점을 그대로 모방하여 자녀와의 신체동작 놀이 상호작용 에서 재현함으로써 놀이 역할 수행과 아버지 상에 대한 새로 운 패러다임을 구성하는 것이라고 할 수 있다. 또한 원 가족 부 모와의 놀이 경험은 현재 아버지가 된 시점에서 아동기를 회 상하였을 때, 즐거운 추억 또는 기억하고 싶지 않은 경험과는 상관없이 현재의 아버지인 자신에게 신체적, 정서적으로 내재 되어 아버지 역할이나 좋은 아버지 상에 작동하고 있음을 알 수 있다. 따라서 신체동작 놀이가 아버지로 하여금 원 가족 아 버지와의 부정적 양육경험을 잊고 자녀와 친밀한 정서적 관계 형성에 도움을 주어 부정적인 경험이나 양육방식이 전이되지 않도록 하는데 도움이 되는 개입 프로그램(S. Kim, 2015)으로 서의 의미를 갖는다고 할 수 있겠다.

넷째, 오늘날 부성담론 속에서 아버지 노릇을 하고 있는 남 성들은 아버지 역할에 대한 개인적인 적응 문제, 사회에서 제 시하는 아버지 상에 대한 압박, 그리고 직장생활이란 사회구 조적 문제 등으로 어려움을 겪고 있다(Hwang \& Baik, 2005). 연구 참여자 아버지들은 신체 에너지 조절력이 부족하고, 반 복적 놀이를 즐기는 영아기 자녀와 신체동작 놀이를 하며 자 녀의 넘치는 신체에너지로 인해 체력적 한계에 다다르게 되었 다. N. H. Kim (2011)의 연구에서는 아버지 역할 수행의 어려 운 점으로 직장에서의 많은 업무량과 그로 인한 휴식 없는 일 과를 꼽았는데, 마찬가지로 연구 참여자 아버지들도 직장과 육아를 병행하면서 시간 부족, 심 없는 일과 속 체력 한계로 인 해 신체동작 놀이에 대한 부담감을 가지게 되었다. 이는 부모자녀 관계를 생성, 유지하는 데 요구되는 물리적, 지적, 정신적 지원뿐만 아니라 신체적 지원의 중요성을 절실히 깨닫게 하는 부분이다. 따라서 ‘체력을 다해 맘껏 신체 놀이하는 아버지’로 
서의 역할과 생계부양자인 가장의 역할을 동시에 감당하는 것 은 결코 쉬운 일이 아니기에 부부 간의 효율적 역할 분담과 이 해, 노력이 신체동작 놀이를 하는 아버지들에게는 더욱 필요 한 부분임을 알 수 있다. 더불어 Kang과 Yoo (2005)는 그들의 연구에서 TV나 주변이야기와 같은 외부 자극이 아버지들의 육아 및 가사분담에 영향을 준다고 하였는데, 실제로 연구 참 여자 아버지들은 신체 놀이로 인한 신체적 노동량에도 불구하 고 프렌디, 플레디와 같이 놀이하는 아버지를 좋은 아버지 상 으로서 지향하는 사회 분위기를 의식하지 않을 수 없었다. 여 기에 더해진 대중매체의 과도한 분위기 조성, 아내의 요구는 아버지들로 하여금 때로는 젠더로서의 남성성마저 희석시키 면서 무조건 수용, 적응하도록 만들기도 하였다. 따라서 사회 적 - 물리적 환경의 변화에 따른 놀이하는 아버지 상에 대한 올 바른 인식 정립과 더불어 아버지들의 역할 갈등과 어려움들을 그들의 입장에서 이해해주는 관점과 노력이 필요함을 알 수 있다. 무엇보다 이는 근본적인 사회적-정치적 기반이 선행적 으로 마련되어져야 함을 시사한다.

다섯째, 영아기 자녀와 신체동작 놀이를 하는 연구 참여자 아버지들은 신체동작 놀이 과정에서 비언어적 몸 동작을 통해 상호 간의 보조, 지지, 반응을 보이며 신체적-정서적 교감을 형성하였다. Youn (2014)은 아버지들은 놀이를 하면서 영유아 와 몸 접촉을 중요시 여겨 몸으로 놀이를 많이 하고, 애착표현 방식으로 신체 접촉을 많이 한다고 하였는데, 실제로 영아기 자녀를 둔 아버지들은 살과 살이 맞닿은 직접적인 몸 접촉을 하며 영아기 자녀와의 동작 하나하나에서 친밀감을 형성하였 다. 결국 아버지와 영아기 자녀 간의 신체동작 놀이는 아버지자녀 간에 정서적으로 연결되는 유대감 형성의 중요한 연결고 리가 되었다. 이는 아버지의 신체동작 놀이가 몸 접촉을 통한 아버지와 자녀 간 애착과 자아정체감에 중요한 영향을 준다는 K. K. Kim (2000)의 연구 결과와도 같은 맥락에서 이해해 볼 수 있다. 연구 참여자 아버지들은 자녀들이 사춘기를 거쳐 장 성한 후에도 자신들과의 신체동작 놀이 기억들이 다시 생기되 고 정서적으로 작용하여 지금과 같이 친밀감과 신뢰감을 바탕 으로 아버지에 대한 존재를 인식시켜주는 선순환의 기능을 수 행할 것이라는 믿음도 갖고 있었다. 결국 아버지들의 신체동 작 놀이가 사회 - 문화적 요구에 응한 것이라 할지라도 아버지 로서의 정체성과 자녀와의 친밀감을 지속, 유지시키고자 하는 내재적 욕구 실현의 한 방편임 $(\mathrm{Na}, 2014 \mathrm{~b})$ 을 알 수 있다.

여섯째, 아버지의 영아기 자녀와의 신체동작 놀이 경험은 아 버지로서의 정체성을 내면화하는 과정이며, 연구 참여자 아버 지들은 영아기 자녀와의 애착 형성을 기반으로 '제 2 의 어머니'
가 아닌 또 다른 양육자로서 각인되어 갔다. K. K. Kim (2000) 은 그의 연구에서 신체동작 놀이에서 아버지의 역할을 잘 수행 하는 것은 자녀와의 정서적 유대감을 증가시켜 영아의 안정감 발달에 도움이 된다고 하였고, Baek과 Seo (2012)는 주양육자가 영유아와 함께하는 활동 중 운동이나 신체 활동하기 등이 애착 상호작용에 정적 영향을 미친다고 하였다. 이러한 두 연구 결 과와 함께 분석해 보면, 영아기 자녀와의 긴밀한 신체적 상호작 용을 통해 이뤼지는 신체동작 놀이가 영아기 자녀에게 어머니 의 신체적 돌봄과 다른 방법으로 안전감을 제공하여, 한 사람 의 남성이 아닌 누군가의 아버지, 보호자로 아버지의 존재감을 인식시켜 준다는 것을 알 수 있다. 또한 연구 참여자 아버지들 은 자녀와 거친 놀이를 하며 어머니가 줄 수 없는 강력한 힘을 통해, 영아기 자녀가 아버지에 대한 존경과 의존성을 갖게 된다 는 것을 인식하게 되었다. 이는 신체동작 놀이가 아버지들로 하 여금 권위를 느끼면서 정체성을 형성시켜주는 요인이 됨을 알 수 있다. 또한 아버지 노릇에서 '권위'를 발견하는 것은 심리적 경험으로써 아버지 됨에 긍정적으로 작용한다는 Steffensmeier (1982)의 연구 결과와 같은 맥락에서 이해해 볼 수 있다.

일곱째, 아버지들은 자녀를 돌보는 과정에서 처음에는 아 내나 양육 지원자보다 능숙하지 못하고, 아내가 자녀와 좀 더 친밀하다는 느낌에서 질투감이나 소외감을 경험하고(Y.-D. $\operatorname{Kim} \&$ Lee, 2011), 수동적인 양육자로서 역할을 수행한다. 하 지만 연구 참여자 아버지들은 신체동작 놀이 경험을 축적하 며 아버지로서 보다 구체화된 책임감과 의무감을 갖게 되었 다. 또한, 자녀의 성장과정을 놀이 상황에서 직접 관찰하며 보 다 생생하고 직접적인 양육 지식과 자녀에 대한 정보 등을 습 득하여, 그동안 어머니의 역할로만 간주되던 자녀의 발달을 점검하고 앞으로의 양육 방향 등에 관심을 갖게 되었다. 이는 아버지 또한 어머니처럼 자녀의 행동과 신호를 민감하게 관찰 할 수 있다는 Y.-K. Kim (2003)의 연구 결과처럼, 신체동작 놀 이 과정에서 아버지들의 세심한 자녀 관찰 과정은 결국 양육 역할을 스스로 지각함으로써 좀 더 적극적이고 구체적인 양육 행동을 보이도록 하는 중요한 부분이 되었다고 할 수 있다. 또 한 연구 참여자 아버지들은 아내와 교육 기관을 통해 배우는 수동적 놀이 학습자가 아닌 놀이성을 회복하고 자녀와 눈높이 를 맞춘 놀이 파트너가 되어가고 있었다. 이는 신체동작 놀이 가 단순히 자녀와 잘 놀기 위한 수단이 아니라 '놀이하는 아버 지, 플레디'가 되기 위한 구체적 실천 방안이자, 자녀를 이해하 고 배려하는 아버지로서 인격적으로 성숙해지는 과정임을 알 수 있다. 결국, 연구 참여자 아버지들은 남성으로서 결혼 후 첫 번째 역할 전이기에 신체동작 놀이 경험 축적으로 자녀의 성 
장 발달을 위한 일차적 역할 수행자를 다른 대상이 아닌 자신 으로 인식하며, 보다 성숙한 아버지로 변화하고 있었다.

여덟째, 연구 참여자 아버지들은 영아기 자녀와 신체동작 놀이 상호작용을 경험하면서 혈연을 넘어선 자녀와의 연대 감을 형성하게 되었다. 이는 원 가족 안에서의 놀이 경험 부 재로 인한 아버지와 자녀 관계에 대한 아쉬움을 극복하고, 가 족이라는 울타리 안에서 아버지로서 삶의 원동력을 찾아 처 음으로 형성되는 아버지와 자녀 관계에 대한 소망을 이루고 자 하는 자기 성찰적 의미를 가진다. S.-Y. Kim (2012)과 Y. M. Park (2009)은 그들의 연구에서 아버지의 양육참여는 부부관 계가 좋을 때 높아지며, 공동 양육자로서 부부가 함께 양육에 참여할 때 화목한 부부관계를 형성할 수 있다고 하였고, $\mathrm{Na}$ (2014b)는 실제적으로 부부가 더 협력적으로 부모역할을 수행 할 경우, 아버지들은 자녀와 더 많이 상호작용하고 삶에 더 관 여한다고 그의 연구에서 밝혔다. 실제적으로 연구 참여자 아 버지들은 신체동작 놀이를 하면서 공동 양육자로서 자녀의 양 육에 대해 서로의 지식과 관점을 수용하고 배워가는 파트너 십을 형성할 수 있었다. 또한 신체동작 놀이라는 양육현장 속 에서 가족애를 형성하고 역동적 놀이 상호작용이 주는 즐거움 과 그 즐거움의 표현인 웃음이 가족관계 내에서 번져가고 공 유되는 것을 경험하게 되었다. 이는 자녀의 성장을 함께하면 서 즐거운 경험을 쌓아가는 것이 아버지 되기 과정에서 큰 기 쁨과 행복이며(Cowan \& Cowan, 1987), 신체동작 놀이를 통한 아버지의 양육 참여가 어려움을 동반한 '부담' 아닌 가족 '행 복'으로의 설계에 토대가 된다는 것을 알 수 있다. 그렇기에 사 회구성원의 삶의 질이나 행복을 위해서는 부모 역량을 제고해 보는 것이 필요하다는 것(Jang \& Yun, 2014) 또한 시사한다.

이처럼 본 연구는 한 사람의 남성에서 아버지로의 전이기 에 있는 영아기 자녀를 둔 아버지들이 그들의 대표적 양육 형 태이자 놀이 방식인 신체동작 놀이를 통해 영아기 자녀와 어 떤 경험을 하는지 살펴보고, 그것이 아버지 되기 과정에 주는 의미를 분석하고, 탐구한 측면에서 의미가 있다. 마지막으로 본 연구의 제언은 다음과 같다.

첫째, 본 연구는 아버지와 영아기 자녀와의 신체동작 놀이 경험을 살펴보고, 그로 인한 아버지 되기 과정과 그의 의미를 탐구하기 위한 연구이다. 따라서 아버지들의 영아기 자녀와의 신체동작 놀이 경험이 잘 드러나는 현장을 연구자의 눈으로 관찰하고 그러한 현장의 주체인 아버지들의 목소리를 담고자, 부모가 함께 참여하는 $\mathrm{G}$ 영유아 신체 놀이 교육 기관을 연구 현장으로 하였고, 신체동작 놀이 수업에 참여하는 아버지들을 연구 참여자로 하였다. 따라서 후속 연구에서는 가정에서의
신체동작 놀이가 어떻게 이뤄지고, 아버지 되기 과정으로서 어떤 의미를 갖게 되는지도 총체적으로 탐구해보는 연구가 필 요할 것이다. 둘째, 앞서 언급한 바처럼 본 연구는 영아기 자녀 와 신체동작 놀이를 하기 위해 특별한 동기를 갖고 기관에 등 록하여 프로그램에 참여하는 아버지들의 사례를 중심으로 그 들의 눈으로 조망하고, 목소리가 담긴 영아기 자녀와의 신체 동작 놀이 경험이 아버지 되기 과정에 주는 의미를 살펴보았 다. 이러한 점은 아버지들의 신체동작 놀이가 좀 더 구체적으 로 이뤄질 수 있는 계획된 놀이 공간에서 영아기 자녀와의 신 체동작 놀이 상호작용이 이뤄지는 현장을 구체적으로 관찰하 고 그들의 생생한 목소리를 담아 연구했다는 점에서 의미 있 는 일일 것이다. 하지만 이러한 아버지들의 신체동작 놀이를 통한 아버지 되기 경험과 의견을 바탕으로 하되, 기관에 다니 지 않는 아버지들의 목소리 또한 담아서 아버지로서의 전이기 에 자녀와의 신체동작 놀이를 통해 성숙한 양육자로서 성장, 발전할 수 있는 다양한 아버지 교육 프로그램을 개발하고 실 행하는 것이 필요할 것이다. 셋째, 연구 참여자 선정에 있어서 본 연구는 한 사람의 남성에서 아버지 전이의 첫 단계에 초보 양육자로서 신체동작 놀이를 경험하는 영아기 자녀를 둔 아버 지들로 한정하였다. 신체동작 놀이 경험과 아버지 되기 과정 에 대한 보다 심층적 탐구를 위해 발달 단계상 신체 움직임이 활발하고, 신체 조절 능력이 정교화 되는 유아기 자녀를 둔 아 버지들의 신체동작 놀이 경험과 그로 인한 아버지 되기 경험 의 의미를 후속 연구에서는 살펴 볼 필요성이 있다.

본 연구 결과를 통해 더 많은 아버지들이 영아기 자녀와 충 만한 신체동작 놀이를 통해 신체적·정서적 교감을 나누고, 친 밀한 관계를 형성하며, 한 사람의 남성을 넘어 아버지로서 부 모 역량, 양육 역량을 키워 가족의 행복을 실현하는 이 시대의 진짜 아버지, 진정한 프렌디가 되기를 기대한다.

\section{Notes}

This article is a part of the first author's master's thesis submitted in 2017. And this article was presented at the 2018 Annual Autumn Conference of the Association of Child Studies.

\section{Conflict of Interest}

No potential conflict of interest relevant to this article was reported. 


\section{Ethics Statement}

All procedures of this research were reviewed by IRB (SMWU1607-HR-044-01).

\section{References}

\section{In English}

Capuozzo, R. M., Sheppard, B. S., \& Uba, G. (2010). Boot camp for new dads: The importance of infant-father attachment. Young Children, 65(2), 24-28.

Clarke-Stewart, K. A. (1978). And daddy makes three: The father's impact on mother and young child. Child Development, 49(2), 466-478. doi:10.2307/1128712

Cowan, C. P., \& Cowan, P. A. (1987). Mens involvement in parenthood: Identifying the antecedent and understanding the barriers. In P. W. Berman \& F. A. Pedersen (Eds.), Men's transitions to parenthood: Longitudinal studies of early family experience (pp. 145-174). New York: Lawrence Erlbaum Associates.

Floyd, K., \& Morman, M. T. (2000). Affection received from fathers as a predictor of men's affection with their own sons: Tests of the modeling and compensation hypotheses. Communication Monographs, 67(4), 347-361. doi:10.1080/03637750009376516

Lamb, M. E. (2010). The role of the fathers: In child development (5th ed.). New York: John Wiley \& Sons.

McBride, B. A., \& McBride, R. J. (1993). Parent education and support programs for fathers. Childhood Education, 70(1), 4-9.

Palkovitz, R. (2002). Involved fathering and men's adult development: Provisional balances. Mahwah, NJ: Lawrence Erlbaum Associates.

Parke, R. D. (1996). Fatherhood. Cambridge, MA: Harvard University Press.

Steffensmeier, R. H. (1982). A role model of the transition to parenthood. Journal of Marriage and the Family, 44(2), 319334. doi: $10.2307 / 351542$

Wolcott, H. F. (1990). Writing up qualitative research. London: SAGE Publications.

\section{In Korean}

Baek, E., \& Seo, Y. (2012, October). Ju yangyukjaga yuawa hamkkehaneun hwaldonggwa yuaui sahoeseong: Aechaksanghojagyongui maegaehyogwareul jungsimeuro [주 양육자가 유아와 함께하는 활동과 유아의 사회성: 애착상호작용의 매개효과를 중심으
로]. Poster presented at the 2012 Annual Autumn Conference of the Korean Association of Childcare \& Education, Seoul, Korea.

Choi, S. (2005). Noliwa yuabaldal [놀이와 유아발달]. Seoul: Yangseowon.

Han, Y. S. (2006). The relation of the father's play participation and child-father relationship, child's social competence with the yypes of children's play. Journal of Future Early Childhood Education, 13(2), 189-212.

Hwang, J., \& Baik, K. (2005). The experience of paternity: Fathers of preschool children. Korean Journal of Child Studies, 26(3), 61-76.

Jang, H. J., \& Yun, E. J. (2014). The current status of parental capacity for children's happiness. Journal of Korean Child Care and Education, 10(2), 295-317. doi:10.14698/ jkcce.2014.10.2.295

Jung, J.-Y., Kim, N.-H., Kim, J.-H., \& Yoo, E.-Y. (2010). The effects of father-child sports activity program on young children's self-competence and fathers' participation in rearing. Early Childhood Education Research \& Review, 14(5), 349-365.

Kang, H.-J., \& Yoo, G.-S. (2005). A study of sharing housework and child care in dual-earner couples-Focused on restraining and driving factors-. Family and Culture, 17(3), 187-219.

Kim, H.-S. (2005). Men's first experience of fatherhood. Korean Journal of Child Studies, 26(5), 73-87.

Kim, K. K. (2000). The effects of father and child physical activity on the development of the child's physical self-competence and social self-competence (Master's thesis). Retrieved from http://www.riss.kr/link?id=T8554232

Kim, N. H. (2011). Early childhood parents' perceptions of good father's roles and social roles for good fathering. Journal of Future Early Childhood Education, 18(2), 79-98.

Kim, S. (2015). Joheun abeojilo sandaneun geos [좋은 아버지로 산 다는 것]. Seoul: Soulmate Books.

Kim, S.-Y. (2010). A study on mother's parent role satisfaction and parenting stress according to father's infant parenting behavior and mother's employment status. Korea Journal of Child Care and Education, 64, 119-153.

Kim, S.-Y. (2012). A narrative study on play interaction experiences of parents with their infants (Doctoral dissertation). Retrieved from http://www.riss.kr/link?id=T12908544

Kim, Y.-D., \& Lee, D.-K. (2011). The parenting characteristics of inexperienced father and the process of becoming father. Journal of Children's Literature and Education, 12(1), 353380.

Kim, Y. H. (1998). Interaction between first-time fathers and their infants (Doctoral dissertation). Retrieved from http://www. riss.kr/link?id=T7110731

Kim, Y.-I., \& Kim, N.-H. (2015). A study of life experiences 
of fathers who actively participate in child-rearing. Early Childhood Education \& Care, 10(2), 191-215. doi:10.16978/ecec.2015.10.2.009

Kim, Y.-K. (2003). A study on father's role perceptions and fathering behaviors in child rearing (Master's thesis). Retrieved from http://www.riss.kr/link?id=T8948710

Ko, J. M., \& Lee, S. Y. (2010). A comparison of mothers' and fathers' responsiveness while playing with their two-yearold children. Korean Journal of Early Childhood Education, 30(2), 147-165. doi:10.18023/kjece.2010.30.2.007

Kwon, H., Kim, K., Woo, H., Jeon, G., Jeon, S., Jung, Y., \& Han, Y. (2016). Play in early childhood education. Paju, KR: Yangseowon.

Kwon, H.-K. (2009). The relations of father's participation in the care of their children, mother's parenting behavior, mother's parenting efficacy, and learning-related social skills of children. Early Childhood Education Research \& Review, 13(4), 79-98.

Kwon, J.-Y., Chung, M.-R., \& Yee, B.-S. (2015). The influence of fathers' play interaction on the cognitive, motor and language development of young children. Korean Journal of Early Childhood Education, 35(1), 333-350. doi:10.18023/ kjece.2015.35.1.015

Lee, B. (2010). (Aileul gwanchalhago naleul seongchalhaneun) Aechag-ui simlihag [(아이를 관찰하고 나를 성찰하는) 애 착의 심리학]. Seoul: Woongjinwellbook.

Lee, H. (2009). A phenomenological approach to the concept of 'Mom' in early childhood education, focusing on Merleau-Ponty's phenomenology of perception. Journal of Early Childhood Education, 29(1), 233-251. doi:10.18023/kjece.2009.29.1.010

Lee, S. (2007). Yualeul wihan nol-iui ilongwa siljae [유아를 위한 놀이의 이론과 실제] (3rd ed.). Seoul: Changjisa.

Lee, Y., Kim, O., \& Woo, H. (2006). (Bumo gyosawa hamkke haneun) Yeonganori [(부모·교사와 함께 하는) 영아놀이]. Paju, KR: Daseossure.

Lim, B.-Y., Kim, Y.-Y., \& Park, H.-Y. (2008). A case study on a movement class to inquire pre-service early childhood teachers' body awareness.: Based on 'discourse of body' by Merleau-Ponty. Korean Journal of Children's Media, 7(2), 37-56.

Merleau-Ponty, M. (2002). Phénoménologie de la perception (E. Ryu, Trans.). Seoul: Moonji Publishing. (Original work published 1976)

Moon, S.-K., Lee, M.-Y., \& Park, S. H. (2009). A study on the factors affecting the wellbeing of parents. Korean Journal of Family Welfare, 14(4), 137-153.

$\mathrm{Na}$, S.-E. (2014a). Fathers' care involvement and the construction of neo-instrumental fatherhood-Focusing on the middle-class fathers in 30-40s-(Doctoral dissertation). Retrieved from http://www.riss.kr/link?id=T13388664

$\mathrm{Na}$, S.-E. (2014b). Men's care involvement and the construction of equal parenting between genders: Focusing on the experience of parental leave. Issues in Feminism, 14(2), 71-112.

Nam, D. H. (2006). Relationship between playfulness of infant and father-infant interaction (Master's thesis). Retrieved from http://www.riss.kr/link?id=T10403387

Oh, Y. J., Cho, B. H., \& Kang, H. K. (2000). A study on preschoolers' physical activities and the fathers' participation. Korea Journal of Child Care and Education, 22, 57-84.

Park, S., \& Lee, J. (2013). Effects of the paternal play involvement activities at home guided by child care providers on fathers' play beliefs and toddler-father interaction. Early Childhood Education \& Care, 8(1), 29-56. doi:10.16978/ecec.2013.8.1.002

Park, Y. (2013). Adongdongjaggyoyug [아동동작교육]. Paju, KR: Kyoyookbook.

Park, Y. M. (2009). Research on the needs for family support service of parents sending their children to day care centers. Journal of Early Childhood Education \& Educare Welfare, 13(2), 241-255.

Ryu, H.-J., \& Lee, J. (2013). Relationships between fathers' play involvement and preshoolers' behavioral self-regulation by child gender. Early Childhood Education \& Care, 8(2), 47 64. doi:10.16978/ecec.2013.8.2.003

Seo, H. (1999). The relations of work-father role conflict with parent satisfaction and parenting sence of competence (Doctoral dissertation). Retrieved from http://www.riss.kr/ link?id=T7124689

Song, H., Ko, S., Park, J., Kwon, H., Kim, Y., \& Jin, M. (2010). Men's father-role in the context of family friendly environment. Journal of Korean Family Resource Management Association, 14(4), 341-361.

Youn, Y. J. (2014). An exploration on the past experience of a 'PlayDaddy' (Master's thesis). Retrieved from http://www.riss.kr/ link?id=T13413233

\section{ORCID}

Hye Ryun Kim http://orcid.org/0000-0001-5117-2804

Eunju Yun http://orcid.org/0000-0002-3641-8834

Received April 30, 2019

Revision received June 24, 2019

Accepted July 24, 2019 